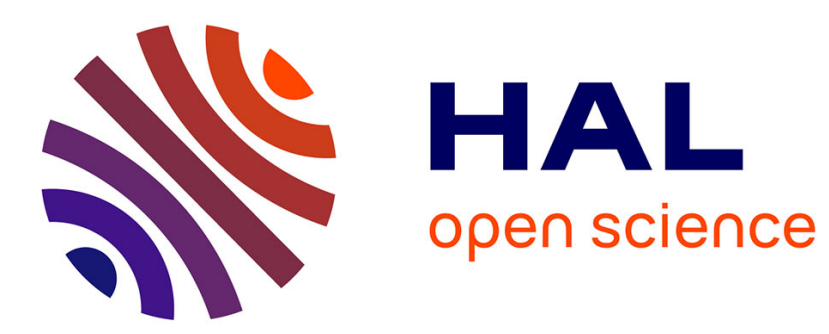

\title{
Stability without a pact? Lessons from the European Gold Standard, 1880-1913
}

Frédéric Zumer, Jacques Le Cacheux, Marc Flandreau

\section{To cite this version:}

Frédéric Zumer, Jacques Le Cacheux, Marc Flandreau. Stability without a pact? Lessons from the European Gold Standard, 1880-1913. 1998. hal-01037858

\section{HAL Id: hal-01037858 \\ https://hal-sciencespo.archives-ouvertes.fr/hal-01037858}

Preprint submitted on 22 Jul 2014

HAL is a multi-disciplinary open access archive for the deposit and dissemination of scientific research documents, whether they are published or not. The documents may come from teaching and research institutions in France or abroad, or from public or private research centers.
L'archive ouverte pluridisciplinaire HAL, est destinée au dépôt et à la diffusion de documents scientifiques de niveau recherche, publiés ou non, émanant des établissements d'enseignement et de recherche français ou étrangers, des laboratoires publics ou privés. 


\section{Stability without a pact ?}

Lessons from the European gold standard 1880-1914

by

Marc Flandreau, Jacques Le Cacheux and Frédéric Zumer

EHESS, OFCE, OFCE

98-01

February 1998 
Stability without a pact ?

Lessons from the European gold standard 1880-1914

Marc Flandreau, Jacques Le Cacheux and Frédéric Zumer*

EHESS, OFCE, OFCE

SUMMARY

The gold standard was a system of fixed exchange rates that offered little opportunity for carrying out monetary policies, short of suspending gold convertibility. Trade integration and capital mobility were very high. It is worthwhile asking whether there are useful lessons to draw for EMU from European experience during that period. One clear lesson is that debts matter. Another basic finding is that the stability of the European gold standard depended on the underlying price trend. Deflation prior to 1895 resulted in rising public debt burdens, which forced some countries to leave the system. Once gold was discovered and deflation

\footnotetext{
*Marc Flandreau is research fellow at the Ecole des Hautes Etudes en Sciences Sociales, associate researcher at OFCE and research affiliate at CEPR. Jacques Le Cacheux is director of the research department, OFCE and Professor of Economics at the Université de Pau. Frédéric Zumer is research fellow at OFCE. We wish to thank Jérôme Legrain for his excellent work as a research assistant in the first phase of the project. Special thanks are due to Roger Nougaret, who heads the Archives of the Crédit Lyonnais, for his kind help in the investigation of sources. We are also grateful to a long list of colleagues either for their contribution in supplying directions to appropriate sources, or for their comments on earlier drafts, or both: Pablo Martin Acena, Michael Bergman, Michael Bordo, Steve Broadberry, Felix Butschek, Forrest Capie, Elio Cerrito, Olga Christodoulaki, Jean-Pierre Dormois, Barry Eichengreen, Curzio Giannini, Paul Gregory, Tim Hatton, Ingrid Henriksen, Lars Jonung, Anton Kausel, Charles Kindleberger, John Komlos, Jacques Mélitz, Leandro Prados de la Escosura, Jaime Reis, Andreas Resch, Hugh Rockoff, Annalisa Rosselli, Max-Stefan Schulze, Pierre Sicsic, Jan-Pieter Smits, Peter Solar, Nathan Sussman, Giuseppe Tattara, Bruno Théret, Jan-Luiten Van Zanden and Vera Zamagni. We also thank Charles Wyplosz, the Editors of Economic Policy and our discussants, whose comments helped to improve the paper's focus. We are especially grateful to the OFCE Documentation Staff (Gwenola de Gouvello and Christine Paquentin) and to the Sciences-Po crew, who were kind enough to ship us unusually large numbers of volumes of the Statesman's Yearbook during the early stages of the project.
} 
gave way to inflation, real interest service fell, debts grew more slowly and a high degree of convergence allowed most countries to return to gold. For EMU, this result implies that stability will hinge on the ECB's policy not being too restrictive. Other lessons concern the fragility of institutions in the face of deep public finance difficulties, the risks for the single market of leaving out countries that have not fully converged, and the existence of a virtuous cycle including low real interest rates, fast growth and debt deccumulation. 


\section{Lessons from the European gold standard, 1880-1914}

\section{INTRODUCTION}

Since the early years of the Industrial Revolution, European countries have, collectively or separately, tried various economic arrangements. These efforts include insulation: commercial protectionism until the Cobden-Chevalier Treaty of 1860 , capital controls from the 1930s to the 1970s, and the free float of the 1930s. They also include periods of openness: fixed exchange rates with the ERM, free capital mobility during the nineteenth century, and increased free trade since the Treaty of Rome. The latest step, European monetary unification, stands as an unparalleled experiment. Or does it? In a sense, it doesn't.

On the eve of the First World War, such heterogeneous countries as wealthy Britain, France and Germany, small open Belgium and Netherlands, the Scandinavian nations, uneven Italy with its leading industrial north and underdeveloped south, backward and agricultural Greece, and even catching-up Russia, all found themselves on a common gold standard with essentially free capital and labour mobility as well as low levels of commercial protection. These 
countries, which hardly formed an optimum currency area, had undergone a common process of institutional reform that resulted in central banks' statutes being designed to foster institutional independence from governmental interference. Some contemporaries even dreamt of a common central bank - although we know the rest of the story.

The relevance of the European side of the gold standard for current debates remains to be fully grasped (Foreman-Peck (1991) is a contribution). In sharp contrast to the current strategy of convergence, which proceeds along agreed common rules (the Maastricht Treaty, the Stability and Growth Pact), the spread of the gold standard to Europe was a highly decentralized process. It was triggered by a lack of co-operation between France and Germany, which led in the early 1870 s to the demise of silver and bimetallic standards in western, central, and eastern Europe (Flandreau, 1995a, 1996). Decentralization was again visible as various European countries hopped on and off gold convertibility in the period between 1880 and 1914 (Eichengreen and Flandreau, 1996). The many international monetary conferences that took place between 1865 and 1892 called for extensive policy co-ordination, but they failed to achieve very much, if anything (Russell, 1898; Gallarotti, 1995). Yet most of Europe ended up on gold, without collectively agreed targets for debt, deficits, inflation, exchange rates or long-run interest rates. To the extent that it succeeded, the European gold standard appears as a case of stability without a pact.

Is it true to say that policy-makers of the time harboured a benign view of monetary policy and public finance? Quite to the contrary, the economic literature of the time shows that contemporaries did worry about the level of public debts, deficits, etc., which were very much at the heart of policy debates (see, e.g., Baxter, 1871). Moreover, the statistical apparatus to assess monetary and fiscal policy was readily available, so the absence of formal criteria cannot be explained by 'technological' limitations. Acceptable measures of activity would start to be constructed only in the years preceding the First World War, but several substitutes existed. General surveys were frequently conducted, and various industrial indices were used to assess 
the economic situation, providing contemporaries with a fair notion of national income. They also had very precise figures on exports and population, and often computed ratios of public debts or flows of interest payment per head in an attempt to compare national debt burdens in a more systematic manner (see, e.g., Théry, 1887). Another view is that the gold standard acted as a kind of invisible (to modern economists) hand, which provided a number of implicit mechanisms that substituted for our modern formal criteria. This traditional interpretation, which dates back to the interwar years, sees the classical gold standard as a coherent system of rules and policies. (For critiques of this view, see Bloomfield (1959) and Triffin (1964); for links with current debates in Europe, see Eichengreen and Flandreau (1997).) Recent work has refined this interpretation by specifying the nature of restraints.

A first view emphasizes the political mechanism. Gallarotti (1995) stresses that the ruling European bourgeoisie wanted stable prices and exchange rates over the long run, because it held a large fraction of its wealth and pensions in the shape of fixed-interest domestic and foreign bonds. The conservative policies that preserved the gold standard are seen as the byproduct of the conservatism of élites. However, in a democratic society, decision making must be transparent and consensual. Monetary stability cannot rest on an arrangement that empowers a specific interest group with the ability to set fiscal or monetary targets. Formal rules are needed to prevent changes in political majorities resulting in fiscal misconduct. The Maastricht « formal rules » approach would be a democratic equivalent of the Gold Standard «political » mechanism.

An alternative view emphasizes the market mechanism. According to Bordo and Rockoff (1996), the gold standard rule worked as an incentive mechanism. Lenders monitored fiscal and monetary misconduct, using gold convertibility as a signal of orthodox policies. Because leaving the gold standard implied higher interest rates, each country had an incentive to adopt disciplined policies. Bordo and Rockoff's point is that this mechanism was stabilizing because disciplined countries were rewarded through lower interest rates: 'countries chose to join the 
gold standard bloc, even though being on gold imposed restraint on their fiscal and monetary behaviour'. ${ }^{2}$ However, nothing in this reasoning is specific to the gold standard. The same incentives should in principle exist under any regime: indeed, the modern literature on financial markets discipline (Bishop et al., 1989) stresses that markets perform the job of providing governments with appropriate incentives. Under this view, therefore, the market mechanism will be an essential ingredient of stability in the Euro zone.

The institutional and market mechanism views of the gold standard correspond to two alternative perceptions of the requisites for a successful functioning of the Euro zone. This paper looks into the historical precedent of the gold standard to determine whether lessons can be drawn for today's Europe. We begin with an investigation of the record of the European gold standard (section 2). Our key conclusion is that the gold standard comprised two subperiods. The first period, starting in 1880 , ended with a severe exchange crisis in the 1890 s. The second period began with exchange rate instability, but then evolved after the turn of the century towards the stable European gold standard. We also find that exchange rate instability coincided in an intriguing way with the record of European debt/GDP ratios.

Section 3 looks at the role of institutional design. Focusing on the record of central bank independence, we find that monetary authorities did not always enjoy the respect and awe that has been portrayed in the literature. Central bank independence was constantly tested, and repeatedly violated, especially when recurrent fiscal difficulties were experienced. It was only after 1896 that central bank independence was gradually reconstructed, suggesting that the degree of insulation of monetary authorities is not exogenous.

Section 4 evaluates the market discipline hypothesis. We contribute to the literature (see Mélitz, 1997) by adding to studies that have looked at existing monetary unions (see, e.g., Bayoumi et al., 1995) a situation where European debt burdens were found at levels that are close to current ones.

\footnotetext{
2 Private correspondence from Hugh Rockoff, which negtly summarizes their view.
} 
Section 5 looks at price movements that affected the opportunity cost of being part of the gold standard. When prices were falling, debt service costs rose and many debt-laden countries suspended gold convertibility. By contrast, countries found it easier to participate in the gold standard when prices rose. To a large extent, divergence and convergence within the gold area can be traced to trends in rates of inflation.

The conclusion sums up the evidence and discusses policy implications. In particular, we suggest that stability will hinge on the ECB's policy not being too restrictive.

\section{LIVING WITH HIGH DEBTS: STYLIZED FACTS ABOUT THE EUROPEAN GOLD STANDARD}

\subsection{European integration and globalization, 1880-1914}

While this paper focuses on Europe as a regional entity, it should be kept in mind that the European gold standard developed in the context of global integration, both real and nominal, and was one aspect of the international gold standard. Capital, as is often the case, was perhaps the most mobile factor and flowed swiftly across borders. Numerous empirical studies have demonstrated that extremely close links existed between regional financial centres in Europe and elsewhere. Short-term capital, in the shape of exchange bills, circulated rapidly from country to country, and short-term interest rates exhibited considerable covariations at both the European (Flandreau, 1995b) and international levels (Zevin, 1992), even during financial crises. Goschen, a contemporary observer, called it the 'solidarity of international financial centres'. Long-term capital also travelled rapidly. Large and well-organized capital markets (the leading centres had a capitalization that represented several times the national product of the corresponding country) provided borrowers with a huge pool of funds on which they could 
tap. Private and public issues took place in co-ordination with banking syndicates that provided underwriting facilities, and became an important outlet for individual savings. As a result, national investment was not limited by domestic resources, thus giving rise to a disconnection between saving and investment. When implementing Feldstein-Horioka's test of the savinginvestment correlation, Bayoumi (1990) and Taylor (1996) found recently that the period 1880-1914 was one of greater disconnection between saving and investment than any subsequent period. These findings are hardly surprising in view of the limited obstacles to financial flows. Even if some governments reportedly attempted to manipulate financial markets for political reasons, they were countered by the competition between lending centres, mostly London, Paris and Berlin. Minor price differences remaining between identical assets traded in different markets were generally traceable to differences in tax systems or other minor frictional costs.

Labour mobility was high too. European immigration laws were usually not very restrictive, and some intra-European mobility existed. Such migrations, however, remained either local (workers crossing the border on a daily basis) or seasonal. These movements were in any case dwarfed by the massive flows of migrants between the old and the new worlds, a factor which, according to Williamson (1996), contributed to the convergence of real wages. Migrants leaving Italy, Germany or Scandinavia helped to relieve the downward pressure on the regions where European wages were lowest.

While capital and to a certain extent labour markets were largely globalized, markets for commodities had a regional bias. European trade was based on short distances, similarities in tastes (Verley, 1997) and generally low levels of protection. The proportion of trade coming from and going to European countries as a share of total European trade generally stood above $50 \%$, in some periods, even above 60\%. Bairoch (1974) notes, however, that European trade became slightly less Eurocentred as it progressed. Rising incomes were accompanied by an 
increased demand for greater variety in imports, and this trend was accentuated by the decline of transportation costs over the period 1870-1914.

Like today, globalization aroused fears of economic decline, especially after the 1890 s. For instance, economist Théry warned that 'emerging countries, newcomers to modern civilization, equipped thanks to the investments of Old Europe, organized by [its] engineers and industrialists, having lands of an incomparable fertility and an almost free labour force, exempt from unions and strikes, [were] on their way to the economic conquest of the world' (Théry, 1894). Contrary to the current situation, the European response to these challenges was not the deepening of the European market, but rather some partial sheltering of domestic economies behind protective barriers. The movement towards extended free trade that had developed after 1860 stalled in 1879, and started receding in the 1890 s. According to Bairoch (1993), the period after 1892 should thus be portrayed as one of gradually rising protectionism in continental Europe. Yet indices of protection before the First World War reveal that Europe was no fortress. Measured as a ratio between customs revenues and imports, protection rates were about $8 \%$ for Europe at large and $10 \%$ for the continent alone (Bairoch, 1993). This was less protectionnist than, say, the USA, Canada or Australia.

\subsection{Gold parities and exchange rates: entry, exit and the spread of the gold standard}

Participation in the gold club was not the outcome of any negotiation. A country only needed to define a gold parity for its currency: that is, the quantity of pure gold in national coins. As long as they effectively maintained convertibility (i.e., stood ready to exchange their notes against coins), central banks indirectly pegged their bilateral exchange rates vis-à-vis other gold convertible currencies within the so-called gold points. These may be thought of as target zones, whose centre coincided with the official parity and whose bandwidth corresponded 
approximately to bullion shipping charges between countries. This was the situation in countries like Britain, France, Germany and the Netherlands. Other currencies, while not strictly convertible, behaved as if they were pegged to gold, because the central bank held foreign exchange reserves and used them to stabilize the exchange rate each time it threatened to exit notional gold points. This was the case in Austria. In other countries, such as Greece in the years immediately preceding the First World War, the national currency was related to gold through what was essentially a currency board arrangement: domestic units were created on a one-for-one basis as a counterpart of foreign exchange reserve holdings.

Since these measures were implemented at the country's convenience, they could always be suspended without international agreement: the option was always available to suspend convertibility, discontinue stabilizing foreign exchange interventions, or quit gold standard arrangements. In this case, the country was effectively dropping off gold and its exchange rate could fluctuate. Historically, such decisions tended to follow periods of crisis, during which money creation had been large and capital inflows low, so that the amount of gold (or reserves) required to settle the country's external obligations was larger than the quantity available in the vaults of the central bank. Once off gold, countries found themselves effectively on a paper standard with a floating exchange rate. The official gold parity represented a floor for exchange rate appreciation, because the central bank that could not sell gold against notes could still sell notes against gold. A country could either undertake to return the exchange rate to its gold parity (a course adopted during the period under study by Portugal, Greece, Italy and Spain), or bring the parity into line with exchange depreciation, accepting a permanent devaluation (a course adopted by Russia and the Austro-Hungarian Empire in the 1890s).

Figure 1 summarizes the spread of the gold standard in Europe. There is, of course, a degree of arbitrariness in deciding where to put the boundary between shadowing a gold standard and not being on a gold standard, but the general pattern would survive alternative 
definitions. This figure reveals a dichotomy between a European 'core' comprising Britain, France, Germany, the Netherlands, Belgium and Scandinavia, and the European southern and eastern 'peripheries'. In the core, the gold standard was a durable regime of unquestioned exchange rate stability. However, in the periphery, adherence to the gold standard was less robust. ${ }^{3}$ Traditional descriptions of the evolution of the gold standard tend to characterize it as a continuous process of extension. More careful scrutiny reveals two periods. The first phase, from 1880 to the mid-1890s, witnessed increasing fragility with fewer countries on gold at the end of the period than at the beginning. Only during the second phase did the gold standard generalize to the periphery of Europe, still leaving aside Spain and Portugal. The era of monetary stability in Europe was in fact circumscribed to the ten years immediately preceding the First World War.

Figure 2 displays the evolution of European exchange rates in terms of end-of-period gold parity, so that a value above unity means the exchange rate is temporarily depreciated. The three key European currencies (sterling, franc and reichsmark) are excluded from the diagram because they remained within their assigned gold points throughout the period. The general pattern exhibits a bell shape. Nearly all exchange rates are located in a narrow $10 \%$ interval. The only exception is Portugal, for which the depreciation was around $20 \%$. For several countries, depreciation was considerable during the 1890s and early 1900s, and was followed by appreciation as the currencies return to the gold standard.

The general pattern conceals three different groups. Small economies, such as Belgium, the Netherlands and Scandinavia, display a very high level of exchange rate stability throughout the period. The second group comprises the central and eastern European empires (Russia and Austria-Hungary). While the exchange rate depreciation that had characterized these countries

3 This feature echoes the descriptions of other peripheral areas, such as Argentina (Ford, 1962). 
until the mid-1880s had come to a halt, their currencies still fluctuated wildly at short frequency (Yeager, 1969). In the early 1890s, the rouble and the florin eventually stabilized around a new, devalued gold parity, which acknowledged the depreciation that had occurred since the 1870s. In both cases no effort was made to go back to the mid-century gold parity, and the devaluation was substantial (about $30 \%$ in the case of Russia). The third group comprises the southern European countries (Greece, Portugal, Spain and to a lesser extent, Italy). For these countries, depreciation began and accelerated after 1890, reaching considerable levels (about $80 \%$ for Greece in 1895, above 65\% for Spain and Portugal in 1898). In the early 1900 s, however, their exchange rates stabilized and then regained lost ground. Only Greece and Italy went back to gold, but Spain and to a lesser extent Portugal experienced a substantial stabilization of their currencies in terms of gold.

Thus the European gold standard was not the strict regime often portrayed in the literature; or if it was, then its rules were repeatedly broken. Moreover, once the rules were broken, there was no reason to expect a quick return to the old parity, as exemplified by Russia and Austria-Hungary. A more adequate picture of the gold standard comprises a stable core with southern and eastern peripheries - an intriguing reminder of today's divisions.

\subsection{Long-term interest rates}

The long-term interest rates shown in Figure 3 were computed as the implicit return on government-funded long-term debt. The corresponding bonds typically bore gold coupons and thus provide us with a measure of the various governments' default risk, because such instruments were not subject to exchange rate depreciation (technically, paying the coupon in paper rather than in gold would amount to a partial default). The diagram shows that interest rates converged only between 1905 and 1913. Among the core countries, convergence was achieved as early as 1880 , and was sustained throughout the period, although some narrowing 
of the range is perceptible in the final years. The other countries faced much higher rates, but they all tended to converge towards the core countries until the late $1880 \mathrm{~s}$. Then a split occurred. While central and eastern European countries (Russia and Austria-Hungary) converged further, southern Europe exhibited an opposite trend.

During the 1890s, 1900s and early 1910s, the spread between central and eastern Europe and the European core continued to decline, only interrupted by the Russo-Japanese war, which caused a relatively mild upsurge in Russian rates. In contrast, in the early 1890 s, interest rates in Portugal, Greece and Spain, and to much more modest extent Italy, bounced up. ${ }^{4}$ A steady decline came later, after the turn of the century: to the Reich's disappointment, Italy's long-run interest rate even fell below that of Germany.

\subsection{Debt/GDP ratios}

The ratios of total debt to gross domestic product are shown in Figure 4. We can observe considerable differences across countries, with ratios ranging from 200\% (Greece, 1890) to $3 \%$ (Switzerland throughout the period). ${ }^{5}$ At the beginning of the period, large debtors (in terms of national income) included Spain (160\%) which defaulted in 1881-2, Italy and France (around 95\%), Portugal, the Netherlands and Austria-Hungary (75\%). Greece and Russia, for which debt/GDP ratios can be computed only after 1885, also entered the scene with ratios around $75 \%$. Thus, more countries were found above a hypothetical $60 \%$ threshold, where the UK roughly lay, than below it: only Germany and some small countries (Belgium, Scandinavia and Switzerland) were found substantially below that level.

\footnotetext{
4 The estimated interest rates that we report take into account the reduction in interest service that these countries implemented. The maintenance of high interest rates after the partial defaults suggests that they did not substantially improve these countries' prospects.

5 For Switzerland, we report only the federal debt. Including cantonal debt would not change the picture much. Note, however, that for other 'federal' or 'confederal' countries such as Germany and Austria-Hungary, the figures we report are inclusive of all regional debts.
} 
Pre-First World War levels tended to be slightly lower. With the exception of Spain and Italy (around 100\%), France and Greece (at about 80\%) and Portugal (120\%), debt/GDP ratios were below $60 \%$. Yet, some initially low-debt countries (such as Germany and Belgium) had experienced a mild increase in their ratio, so that intra-European differences were smaller than they had been in the past. This evolution, far from continuous, conceals a general trend of initially increasing and then declining ratios (the exception being Britain, where the decline was steady). The coincidence between this movement and the post-1900 process of long-term interest rate convergence observed in Figure 3 is striking. It suggests that long-term interest rates are a broad measure of default risk. This pattern contradicts the received wisdom - based on the American and British experiences - according to which public debts rose in periods of war and declined in periods of peace. With peace prevailing during the period, military shocks were relatively few. Even when wars occurred and led to debt accumulation, the broad trends were not reversed, as can be seen from the case of Russia during its war against Japan, or of Greece at the time of the Balkan crises after 1900. Conversely, debts rose before domestic or external unrest, as exemplified by Spain and Portugal until the mid-1890s. The rise of continental debts in the midst of the pax britannica suggests that current European concerns with high debts in fact have very old precedents.

Summarizing, we find that during the period of the gold standard, European countries went through a largely common trend of rising and then declining debts. This process was accompanied by co-movements in long-term interest rates and exchange rates. The heyday of the gold standard was in fact circumscribed to the years between 1900 and 1913, when spreads between exchange rates, interest rates and debt/GDP ratios were decreasing. It does not cover the whole period between 1880 and 1913, as is often assumed. As we reconsider the overall experience, we seek to determine the common causes of varied experiences, in contrast to the traditional focus on the common causes of an alleged common success. 


\section{INSTITUTIONAL FIXES: DEMOCRACY, CENTRAL BANK INDEPENDENCE AND THE SPREAD OF THE EUROPEAN GOLD STANDARD}

In this section, we document the contribution of institutional arrangements to monetary stability under the European gold standard. Our goal is to try to assess the extent to which the features documented above can be ascribed to institutions.

\subsection{Politics and institutions: the gold standard record}

As shiny as gold may be, it cannot be used to stabilize debts that have been monetized. Fiscal misbehaviour inevitably leads to a gradual depletion of gold reserves, usually accompanied by a speculative attack and exchange depreciation (Flood and Garber, 1984). What matters is the decision-making process within the gold standard, hence the importance of relations between monetary authorities and the polity. It is often believed that, before 1914, monetary authorities remained largely insulated from politics and were able to commit themselves credibly to the maintenance of stable exchange rates. This claim (which can be traced back to Polanyi (1944)) has taken a variety of forms. Some authors have argued that the pre-1914 period was one of universal central bank independence. For instance, Capie et al. (1994) have argued that monetary laissez-faire (by which they meant limited government intervention) emerged in the nineteenth century and dominated throughout the years 1880-1914, until it was repealed during the war. Under this view, most analyses tend to focus on the relationship between central and commercial banks (see, e.g., Goodhart, 1988). Very few recent studies document the long swings in central bank independence (partial exceptions include Holtfrerich (1988) and Bouvier (1988), who briefly discuss the pre-1914 period for Germany and France; Capie et al. (1994) also discuss the issue briefly, and it is dealt with more extensively in Capie (1997)). 
The modern prejudice is that central banks were de facto in the hands of the financial establishment, which thus implemented its preferred policies independently of what the public felt (Gallarotti, 1995). Eichengreen $(1992,1996)$ further suggests that the restrictive electoral franchise, the limited strength of trade unionism and the dearth of parliamentary labour parties helped to reduce distributional conflicts because those who were in charge of monetary policy were those who suffered least from its effects. Painful adjustments that resulted in wage contraction were always feasible, since workers did not have a say. Table 1 reports estimates of the registered electorate as a proportion of the enfranchised age group (see Flora et al. (1983) for a discussion of the methodological problems involved in this measurement). ${ }^{6}$ The extension of the franchise in the latter part of the nineteenth century corresponds to the gradual elimination of exclusions based on income as well as reductions in the list of requirements. By the turn of the century, remaining exclusions for men included the homeless, convicts, those with criminal records or in asylums, and those who had recently changed residence; for them, and for women, democracy would have to wait. But workers were in general no longer excluded.

Table 1 does not suggest a direct link between limitations on democracy and the stability of the gold standard. In fact, the trend towards extended franchise coincides after 1900 with the decline in debt/GDP ratios. For instance, in Italy, universal suffrage was granted only in the early years of the twentieth century, after the lira was firmly stabilized, and it did not weaken the lira. It is during these years that the yield on Italian bonds fell below the German level. Similarly, exchange rate instability in Austria coincided with a restricted

\footnotetext{
6 The figures are (politically incorrectly) constructed on the basis of the male population only, since such was the way universality of voting rights was understood at that time. From the point of view of our argument this restriction matters only if potential female voters would have systematically favoured less conservative interests.
} 
franchise, while stability again coincided with an extended franchise. Conversely, core countries such as Germany and France had granted universal and equal suffrage well before the period under study (in 1871 and 1848 respectively). Many authors may have been influenced by the case of Britain, where a restricted franchise did indeed coincide with monetary stability. But on this dimension, when all of Europe is taken into account, Britain stands as an exception.

\subsection{Central bank independence, 1880-1914: doctrines and features}

No view could be more distant from the concerns of economists in the 1890s and 1900s than the modern prejudice that central bank independence was the normal state of affairs during the gold standard. In the years immediately preceding the First World War, the protection of central banks against political pressures was indeed high. However, this was perceived by contemporaries as being the result of a patient construct which, in a large number of European nations, had only recently been completed. Summarizing in 1911 a view that had developed in the profession over the past half century, leading monetary expert Raphaël-Georges Lévy refers to the 'theory that calls for the separation of the central bank from the State' (Lévy, 1911). This theory has a surprisingly familiar ring: according to Lévy, central bank independence was an absolute prerequisite for exchange rate stability, because a nonindependent bank would lead market participants to expect eventual debt monetization. As a result, central banks or banks of issue served public treasuries better if their 'existence [is] more independent, and their administration more separate, from that of the State. The less public authority gets involved into the management of the banking system, the better national

Yet as Scandinavian socialists would learn to their expense in the 1900 s, women's right to vote often resulted, in the short run, in more conservative outcomes, not more leftist ones. 
credit and wealth are protected.' On the eve of the First World War, Lévy wrote approvingly of the progress of central bank independence.

Central banks initially developed as the interface between the banking and industrial communities and the state. On the one hand, the banking and industrial communities needed a central bank to implement some minimum level of co-ordination among financial institutions, most importantly to provide lender of last resort functions in periods of crisis. For this purpose, co-operation of state bodies was necessary, as special laws and decrees had to be passed. On the other hand, the state wanted easy access to credit, as well as influence over monetary policy: for instance, favouring certain groups or making credit more abundant in a protoKeynesian way (as argued by Kindleberger (1988), public works and fiscal stimuli were not an invention of the 1930s). States and banking or industrial communities had thus both common and divergent interests, and central banks' charters were the locus where the balance of power both crystallized and could be renegotiated.

Governments could extract seigniorage in two ways. They could force the central bank to monetize the debt and they could directly circulate government notes independently of the central bank. Following Cukierman's (1992) distinction between limitations on lending and ways to influence decisions, two features of central banks' charters are of interest. Direct political control is linked to the ownership of the bank (privately or state owned), the appointment of the board (governor, sub-governor(s) and council), as well as rules governing the cover system. Obviously, the greater the private sector ingredient in the decision-making process, the more constrained was the government (Capie (1997) makes a similar point). Indirect control rests on rules governing the government's right to obtain short-term advances, to monetize securities, or to issue its own paper. One should not take a nominalist view of such features. Statutes were not resources lying exclusively in the hands of central bankers or governments. They were the endogenous outcome of negotiations that codified state-bank relations when charters were drafted, and their adjustment over time followed, rather than 
preceded, actual changes in underlying power relations. Leads and lags existed between printed norms and actual behaviour. For instance, the central bank's need to obtain on occasions a renewal of its charter, especially in the presence of a potential competitor, reduced its actual bargaining power well below what statutes suggested, especially as the renegotiation of the charter approached. Moreover, 'invisible' threats could very well distort actual practices. On the other hand, the need for the government to secure a minimum level of co-operation from the banking community (for instance, when large public loans were floated) certainly checked its incentive to exploit the bank of issue. ${ }^{7}$

\subsection{The good guys}

Table 2 summarizes the information for the three core countries (Britain, France and Germany) and Table 3 focuses on smaller economies (Belgium, the Netherlands and Scandinavia). For these eight countries, which were steady members of the gold club, we find substantial balances in the relationship between government and the central bank. Statutory limits usually applied to automatic credit lines, which were kept to minimum, when they existed. Issues backed by government securities were tightly regulated. Additional requirements pertained to the cover system. Taken together, these measures made sure that the bank would always have enough free resources to invest in private bills (as opposed to government paper), while providing for an appropriate cover ratio. These protections were often further supported by the balance of power on the board. Because the central bank was often a private corporation, it had to include some representation of the shareholders. Interestingly, in Sweden, the only country in this group where it was state owned, the central bank was explicitly made

\footnotetext{
${ }^{7}$ Posen (1994) supports the endogeneity view largely held among economic historians Alesina (1994) presents the mainstream economists' counterview.
} 
responsible not to the Treasury but to Parliament, to which it had to report. In all eight countries, parliamentary audits of central bank action and accounts generalized over time.

This broad pattern, however, conceals national idiosyncrasies. Britain, the Netherlands, Belgium and the Scandinavian countries had the most independent central banks. All combined a fair amount of independence in the decision-making process with statutory requirements regarding their cover system, advances to the state, and issues on the basis of government securities. In France, however, almost no formal rule existed regarding either the cover system or limitations on government credit. Since parallel issues were not authorized, reserve ratios and investment in public securities depended on the balance of power on the bank's board (the Conseil Général). The independence of the Bank of France thus rested on the ability of shareholders to impose their decisions during board meetings. They were indeed able to outvote government officials, but the checks and balances that prevailed in some other countries was lacking. ${ }^{8}$ Ironically perhaps, Germany had the least independent central bank of the group. Large powers rested in the hands of the Chancellor of the Empire, who effectively directed the bank through a technocrat. The shareholders' role was limited to auditing and certifying the bank's accounts. Their delegates could participate in board meetings, but their votes were not taken into account. Most checks rested on the set of formal rules governing note issues (see James (1997) for a congruent view). Much of the discipline was exercised through the cover system, which put a lower limit on the specie reserve. The fact that the Chancellor needed shareholders' support from time to time (for instance, when the capital of the bank had to be increased) also fostered compliance to these agreed rules.

\footnotetext{
8 The absence of formal constraints left more space for bargaining. This has led historians of the relations between the Bank of France and the state (Bouvier, 1988; Plessis, 1985) to conclude that the bank was not very independent. That the Bank of France was able to implement deflationary policies when needed, and even when this did not suit the government, is in our view the proof of its effective autonomy.
} 


\subsection{Central bank independence in the European periphery}

3.4.1. Central-eastern Europe. In eastern and central Europe, State-bank relations changed over time and differed from those prevailing in core countries (Table 4). In Russia the bank was owned and controlled by the state. The cover system, initially modelled on the British system, nominally imposed tight limits on the issue of banknotes. These limitations quickly lost significance as the Treasury started to circulate its own notes. Moreover, while issues based on government bonds were limited, short-term advances to the state were unlimited. Several schemes were tried as the rouble depreciated in the 1870 s and fluctuated in the $1880 \mathrm{~s}$, but reform had to await the final consolidation of Russian finances in the early 1890s. While the central bank remained under state control, a number of decrees provided for strict limits on note issues by the government. The Russian Treasury borrowed on international markets to purchase the bank's gold reserve. In 1897 the system took its final shape with a regime that provided for one of the highest cover ratios on the continent, and ruled out parallel issues. Contemporaries were generally impressed. For instance, Conant (1915) concluded that 'the history of the Bank of Russia is of interest, because it is the most successful instance on a large scale of a bank of issue owned by the State, and because it carried through in the closing decade of the nineteenth century the most serious operations ever undertaken in Europe for the restoration of stability of exchange upon a gold basis'. Of course, this policy could be reversed in a matter of days by a few decrees. The Bank of Russia's independence was credible only inasmuch as nobody expected the Treasury to change its policy stance.

The Austro-Hungarian case reveals some similarities. Until the late 1870 s, the central bank was the Bank of Austria. While private, it operated under the control of the Austrian Treasury, which could obtain short-term advances and force the bank to take up its securities. As in Russia, the Treasury could short-circuit the bank and issue government notes: in 1877 these issues had reached 350 million florins at a time when central bank note issues totalled 
about 300 million. This situation created considerable uncertainty and the exchange rate fluctuated widely. In 1878 the statutes of the Austrian central bank were redrafted. Under pressure from Hungary, the central bank, renamed the Austro-Hungarian Bank, came under joint control of both Austria and Hungary. This situation was further consolidated in 1887 with the introduction of a combined system of fractional reserve and minimum cover ratio, which provided tight limits on direct government seigniorage. In 1892 a set of monetary laws laid the foundations for the adoption of the gold standard. The outstanding government paper money would have to be repurchased gradually, and the Treasury would no longer be allowed to issue notes. Statutory advances were kept to a minimum and government bonds were not allowed to be part of the reserve. The Austro-Hungarian Bank was gradually converging towards western European standards.

3.4.2. Southern European countries. Southern European countries provide a graphic illustration of how easily independence can be suspended in the face of serious fiscal difficulties. Treasuries in the four southern European countries usually refrained from directly issuing notes. They preferred to use statutory advances and automatic credit on government bonds. While initially limited, these facilities were gradually extended during the second half of the 1880s. For instance, in 1887 both Portugal and Greece loosened the constraints on shortterm advances. The process accelerated in the early 1890s. The Spanish government decided that the bills issued to finance the Treasury's overseas expenses would be discounted by the Bank of Spain, which was further forced in 1891 to grant a large credit to the state. In Portugal, Greece and Italy, short-term advances were made to the Treasury in exchange for the deposit of government bonds, sometimes almost at will. Limits on note issue were repeatedly raised.

Italy was the first country to take decisive remedial steps. In 1893 it imposed tight limits on government credit and added a $40 \%$ cover system to its central bank. Greece 
followed suit in 1898 after the international rescue package, put together to help Greece pay its indemnity to Turkey, led to a shift in the balance of power between the bank (which had in the past unsuccessfully sought to resist government intervention) and the Treasury. Now under close creditor control, the Treasury's ability to pressurize the central bank was substantially reduced. Additional automatic advances were ruled out in 1899 and, finally, investment in public securities was kept to a statutory maximum.

In Spain, reform started under the Villaverde ministry, at the turn of the century. In 1902 it was decided that short-term advances to the Treasury should be gradually reimbursed. While investment in public securities was still unlimited, the Treasury made a substantial effort to consolidate its balance sheet and repurchase the former advances, and this in turn succeeded in consolidating the bank's reserves. The proportion of specie in the reserves grew at the expense of government bonds. In Portugal, efforts at separating the central bank from the state remained elusive. Until the end of the period, the Portuguese Treasury continued to draw on the Bank of Portugal by depositing depreciating government securities in exchange for shortterm credit. This easy door to monetization was never shut, and the political turmoil of the last years before the war led to a return to automatic central bank credit and exchange rate fragility. On the eve of the First World War, Portugal had the least independent central bank and was not in sight of the gold standard.

\subsection{Conclusion}

It is clearly impossible to claim that central bank independence was the European gold standard's recipe for monetary stability. Rather, poor exchange rate performance was associated with low levels of central bank independence. Much like today, contemporary 
observers concluded that central bank independence was the exogenous source of stability. Yet the evidence suggests that institutions were extremely fragile and never resisted the pull of fiscal problems. The evolution of Southern European central banks' statutes in the 1890s demonstrates that the protective walls that appeared so safe in core countries could very well crumble. Eventual efforts towards better protection of monetary authorities were in fact led by governments (Raffalovich, 1900). Central bank independence thus came and went as fiscal needs changed. Public finance problems led to the collapse of Mediterranean currencies in the 1890s, and their resolution led the way out. The consolidations in Italy, Spain and Greece had not been imposed on the Treasury by a powerful central bank. Rather, the increased autonomy of the central bank resulted from the Treasury's ability to balance its accounts. In Russia and Austria, treasuries even provided the central bank with a critical mass of gold reserves. In the next section, therefore, we consider how constraints on debt accumulation might have influenced both exchange rate stability and central bank autonomy.

\section{IN SEARCH OF THE MARKET MECHANISM}

\subsection{Market discipline: the weak, the strong and the ugly}

According to the market discipline hypothesis, lenders charge higher interest rates to borrowers whom they consider riskier, which in turn discourages risky behaviour. The 
question, of course, is to determine what defines risky behaviour. Bordo and Rockoff (1996) ask whether adherence to the gold standard was the signal that markets used to judge countries. They find that long-term interest rates are indeed statistically lower in countries on the gold standard, once account is taken of fiscal and monetary conditions. ${ }^{9}$ Faced with higher interest rates, countries with a poor record of adherence to gold felt the incentive to put their house in order. In other words, the gold standard acted as a 'good housekeeping seal of approval'.

The market mechanism is undoubtedly an important part of any comprehensive picture of the gold standard, but its implications for EMU must be considered carefully. It is not only membership of a given club (the gold standard then, EMU tomorrow) that markets monitor, but more broadly the credibility of policies which in turn permit the participation in that club to be maintained. This distinction matters a lot for EMU because a strict interpretation of Bordo and Rockoff's results could be that, once countries commit to a permanently fixed exchange rate, the seal of approval mechanism is lost. Yet there are grounds to believe that markets will discriminate among EMU member governments - as opposed to countries - paying particular attention to fiscal policies.

In this section, consistent with modern analyses of market discipline (e.g., Bishop et al., 1989), we focus on the pricing of government bonds. Three possible patterns are tried, as explained formally in Box 1. The first pattern may be interpreted as the weak form of the market discipline hypothesis. It posits a linear relationship between risk premia (measured by the spread between the country's long-term interest rate and a (risk-free) British consol) and debt levels (measured by debt/GDP ratios). This specification assumes that increased indebtedness is costly, but that the marginal cost of increased indebtedness is constant. Supplyside incentives for fiscal orthodoxy do not change as debt accumulates. We will refer to this weak version of the market discipline hypothesis as the 'linear form'.

\footnotetext{
${ }^{9}$ The sample used by Bordo and Rockoff only partly oxgrlaps with ours.
} 
We consider two additional specifications. Both assume that the relation between debt levels and interest rates is non-linear: more specifically, that the marginal cost of borrowing increases with the debt level. The 'credit punishing' specification - the strong form of the market discipline hypothesis - posits that borrowing costs grow exponentially with the debt level. This specification assumes that debt accumulation increases the probability of default. In contrast to the linear form, the growth of the marginal cost of borrowing creates a growing disincentive for debt over-accumulation. Finally, the 'ugly' form of the market discipline hypothesis considers that there exists a debt threshold beyond which the sovereign is no longer able to borrow because lenders react to the risk of default by rationing borrowers (Stiglitz and Weiss, 1981). Technically, the credit supply schedule has an asymptote (an infinite limit) at the level of indebtedness where rationing occurs. We refer to this last version of the market discipline hypothesis as 'credit rationing'. ${ }^{10}$ Clearly the linear mechanism provides weaker incentives to borrowers than the punishing or rationing ones for high debt levels.

\subsection{Estimation results}

We use our panel of European countries to examine the link between indebtedness and the cost of borrowing by regressing the spreads of government bond yields over a risk-free bond on the debt/GDP ratios. Our regressions also capture the effect of economic fundamentals that may influence debt sustainability. These include the exports/GDP ratio and levels of economic development measured by using real GDP per head converted at PPP prices. We also included an 'on gold' variable, which takes the value 1 when the country is on gold in any given year,

10 This latter form of the market discipline hypothesis was applied to US states by Bayoumi et al. (1993). Their findings imply that American states are rationed at relatively low debt ratios, all below $10 \%$ of gross state product. These thresholds are far below what was observed under the gold standard, and far below current 
and zero otherwise. ${ }^{11}$ This variable may be interpreted as either capturing the additional effect of market discipline in rewarding countries adhering to gold (the seal of approval view) or reflecting a number of factors that were known to market participants, but which are not included in our data set and which were correlated with adherence to the gold standard (e.g., political shocks).

The results of pooled regressions are shown in Table 6 . We use instrumental variables (see Appendix B for details) with explanatory variables alternatively included in and excluded from the estimation. The results range from the most parsimonious specifications (only debt ratios are included) to the most extensive ones (all exogenous variables are included). In all regressions, the parameters are generally found statistically significant and their signs correspond to economic intuition. The negative effect of per capita income reflects the fact that economic development is typically accompanied by a greater ability to tax, and hence improved debt sustainability. The negative effect of openness captures the fact that in nineteenth-century Europe, capital exporting countries were also the most open ones. Open countries were usually capital lenders and had a greater ability to retain foreign investment; hence they were better able to deal with external payment problems (Bairoch, 1974). The signs of the debt and 'on gold' variables clearly fit the previous discussions.

Judging from the fit (adjusted $R^{2}$ ), the non-linear specifications (panels a and c) do a better job than the linear specification (panel b). This conclusion can be rigorously tested when comparing the 'rationing' and 'linear' specifications, since the latter can be seen as imposing on the former the restriction that the 'debt rationing' coefficient is zero. This restriction is clearly rejected. Additional tests presented in Appendix B do not discriminate clearly between the two

European debt levels. This suggests that the overall economic and institutional context in which US states accumulate debts is quite different from the European one, past, present and future.

11 We favour the latter interpretation. Indeed our model, contrary to Bordo and Rockoff's, shows a very good performance of all structural variables. For instance, debt levels matter a lot in our regression, while in their work, fiscal and monetary variables turned out to be non-significant. In Bordo and Rockoff, only dummies and quasi-dummies bore the brunt of the explanatory power. This suggests that more work should be done before we can make sure that this « seal of approval» mechanism had an independent action. 
non-linear specifications. In fact, for our current purpose, it is enough to observe that both specifications point to similar conclusions. The rationing hypothesis suggests precise but very high rationing thresholds. This means that rationing, even if it took place, occurred at such high debt levels that the difference between the 'punishing' and 'rationing' views is a matter more of taste than of substance.

In order to study the robustness of our results, we performed a full series of tests reported in Appendix B. These include tests for pooling, tests of coefficient stability allowing for countryspecific effects, excluding problem countries (e.g., Greece and Portugal), tests of sub-sample stability over the two periods identified in the paper (before and after 1895) as well as checking for the validity of our instruments.

The conclusion that emerges from the previous statistical exercises is that the gold standard experience by and large supports the view that markets react to increases in debt burdens by inflicting increasingly higher risk premia. On the other hand, countries had to plunge quite deep into debt before they started feeling the pain. This can be illustrated by the fact that long-term interest rates converged after 1900, while debt levels remained as high as $100 \%$ of GDP in some countries, implying that at this level, markets did not inflict massive punishments. That debt burdens seriously mattered only when they reached fairly high levels suggests that the market mechanism, while certainly a strong incentive, did not provide absolute discipline. The same market mechanism was in fact in place both during the period of rising public debts and at the time of steady decline during the Belle Epoque. Clearly some other factor must have driven the flow and ebb of European public debts.

5. CONVERGENCE BY OTHER MEANS: LOST RECIPES FROM THE GOLD STANDARD 
In this section, we argue that price movements constitute a key factor in the behaviour of debts ratios. In the late nineteenth century, price trends went through two subperiods which interestingly coincide with the evolution of public debts. Prices moved down between 1873 and 1896, and then up until the war - a tendency perceptible in all countries adhering to gold, in Europe and elsewhere. There is general agreement that these trends can be explained by the supply of gold. Gold was too scarce to avoid deflation in the wake of the decline in the monetary role of silver after 1873 , but it suddenly became abundant following discoveries in South Africa and Klondike in the 1890s. While it obviously matters how central banks reacted, for our purpose it is enough to assume that they were essentially passive as they stuck to gold. Indeed, Barsky and De Long (1991) show that gold output was a good predictor of inflation in gold standard countries, implying that central banks in the gold zone did not fully sterilize the effects of gold discoveries.

The considerable degree of covariation of price levels across gold standard countries is abundantly documented. For instance, McCloskey and Zecher (1984) even argue that the observed price correlation was responsible for the smooth operation of the gold standard: countries on gold were like the 'regions' of a single area. Having shown, however, that the gold standard did not operate particularly smoothly in Europe, we need to revisit the role of price fluctuations. Price dynamics could generate pleasant or unpleasant fiscal arithmetics, depending on whether prices were moving up or down. A fall in the general price level meant, other things being equal, rising levels of debt ratios. With constant GDP and tax revenues, falling prices meant an increase in the burden of interest service on outstanding long-term debt. In contrast, a rise in prices would reduce the burden of the outstanding nominal debt. In other words, governments were collecting an inflation tax when prices were steadily rising, and paying a deflation premium when prices were steadily falling. 
To illustrate the mechanism at work, we decompose the dynamics of the debt/GDP ratio into its components: the ratio of primary deficits to GDP (that is, the deficit before interest service is taken into account), the ex-post real interest service and, finally, real GDP growth. Higher real interest service or higher primary deficits contribute to raising the debt burden, whereas higher growth contributes to reducing it. ${ }^{12}$ Figure 5 describes the evolution of these three components for the set of countries for which data on public debt service were available. Several features emerge. First, primary deficits did not change dramatically at the turn of the century. Indeed, the five-year averages that we report indicate that, for a number of countries, there was a deterioration rather than an improvement. Debt reduction must have come from somewhere else. This is especially visible for peripheral countries such as AustriaHungary, Italy and Russia, where debt ratios went down by substantial amounts. The improvement in debt ratios can be traced back to a combination of drastic declines in real interest service and an acceleration of growth. Real interest service fell from rather high levels in the early 1880 s to record lows after 1905 : they went from $8 \%$ to $1 \%$ in Italy, from $5 \%$ to $3 \%$ in Austria, from $6.5 \%$ to $1.5 \%$ in Germany, etc. Even without the contribution of improved growth prospects, as inflation progressed, public debt sustainability improved, and the default risks that sovereign borrowers faced declined. The acceleration of growth that some countries experienced at the turn of the century helped further. However, this tendency was perhaps less systematic than the effects of gold inflation. For instance, growth was marked in Austria, Russia and Germany, but much less so in Britain and France.

This mechanism was amplified by the predominance of the long-term component in European sovereign debts: the inertia of the interest service on this fraction of public debts was

\footnotetext{
12 Let $b(t)=B(t) / G D P(t)$, be the ratio of nominal debt $B$ to nominal GDP, $r(t)$ the real (ex-post) interest rate, $g(t)$ the real growth rate, and $\operatorname{def}(t)$ the primary deficit divided by GDP. Then the total deficit, or accumulation of debt is: $d b(t)=\operatorname{def}(t)+(r(t)-g(t)) b(t)$.
} 
the channel through which price movements affected public finances. ${ }^{13}$ Through their effect on public finances, price trends in turn influenced governments' incentives to participate in the gold standard. Deflation forced a difficult choice between deteriorating borrowing conditions and painful adjustments. Countries starting with relatively low debt levels could compromise, letting their debt drift slightly and making only partial fiscal adjustments. But for those that already had fairly high debt levels, such as the southern European countries, the adjustment cost required for continued participation in the gold standard could be very large, especially since the market mechanism implied that a sustained deterioration in public debts meant accelerating premia for new loans. The opportunity cost of being part of the gold standard was becoming very substantial, increasing the pressure to switch to seigniorage finance, and go on inconvertible paper to escape gold deflation. On the other hand, when prices rose, countries were suddenly able to reduce the cost of new loans (as debt levels decreased), while facing a lower real cost of interest service on existing indebtedness. Thus inflation provided an additional reason for participating in the gold club.

Summarizing, price trends, of which no single country had control, strongly affected incentives to belong to the gold club. Indeed, club membership followed the trends: deflation until the mid-1890s, inflation afterwards. Moreover, in periods of deflation, as public finances tend to deteriorate, the price of central bank independence rises. Central bank independence did not survive in the most heavily indebted and economically vulnerable countries. Markets were trapped when falling prices pushed the highly indebted countries to breaking point. Under these circumstances, market discipline and central bank independence could only be selfdefeating. By contrast, after the mid-1890s, governments could both better listen to the markets' wishes and reduce default risk. The second factor facilitating consolidation of the

13 We do not have a precise breakdown of the proportion of short- and long-term debts for all countries in the sample. Various indications suggest that long-term 'funded' debt represented more than $90 \%$ of the aggregate public debt in countries like Britain, Germany and France, and even Russia and the Austro-Hungarian Empire. It fell to lower levels (still above 50\%) in other peripheral countries. 
gold standard after the mid-1890s was improved growth in a number of countries (most notably members of the periphery) at the turn of the century. Of course, it is likely that inflation and growth trends were related, since the decline in long-term real interest rates facilitated investment and growth. With growth rates rising above interest rates, debt burdens receded, bringing about the golden age of the European gold standard.

\section{CONCLUSION}

Economists have long scrutinized the gold standard sphinx, trying to understand its riddle in the hope of discovering lessons that could help bring back the golden age. In fact, the gold standard heyday was a rather limited period, extending from the late 1890 s or early 1900 s to the First World War, not the whole 1880-1913 era, as is often believed. This evolution, so far little noticed, conveys several interesting lessons. First market-imposed discipline was a very important aspect of the gold standard and will certainly matter under EMU. However, it cannot be relied upon exclusively to provide borrowers with appropriate incentives. Incentives even become destabilizing when unexpected deflation adversely affects public finances. This lesson supports formal limitations on debts or deficits. On the other hand, debt ratios above 
$60 \%$ are not a hindrance provided that they are on a declining trend. The European gold standard could survive with high and varied debt levels, but its consolidation coincided with a period of general decline in debt ratios.

The second lesson for EMU is that denying admission into the Euro zone may not be the best way to solve the systemic risk of debt over-accumulation. Externalizing that risk may create other problems. Left to themselves and to the imperfect discipline of financial markets in the early 1890s, southern European countries borrowed too much and were found high and dry when the cost of borrowing surged. Exchange depreciation in the periphery in turn created protectionist pressures in those countries of the European core which still had a large agricultural sector, such as France. This is a clear reminder that the benefits of externalizing fiscal discipline by limiting the Euro zone to a small number of countries must be balanced against the costs of endangering the single market.

Our third lesson concerns the successful record of eastern and central European peripheries. Even under the most lenient application of optimum currency area criteria, these relatively backward countries would not have qualified for gold area membership. Yet the exceptional growth that Russia and Austria-Hungary experienced after 1900 suggests that continued adherence to the gold standard provided them with all the benefits of low interest rates, including declining debts and better growth prospects. It might well be that, by the same mechanism, some countries of the current European periphery will be among the big winners of EMU.

Finally, our analysis highlights the importance of finding a proper balance between discipline and incentives. The gold standard turned out to be hostage to the exogenous evolution of prices. Over the period 1873-96, the declining price trend exacerbated the public finance problems of the periphery to breaking point. After 1896, by contrast, inflation made convergence and steady participation in the gold zone much more attractive. Governments 
became more eager to conform to the discipline that markets required. The clear implication for EMU is that its stability will hinge on the ECB's policy not being too restrictive.

In the end, the heyday of the European gold standard was an accident of history. It came about when steady gold inflation moderated national incentives to extract seigniorage and brought about a reduction of debt burdens that contributed to lower interest rates. This in turn facilitated growth and the convergence process. Exchange stabilization and the spread of central bank independence followed. To what extent could such a regime survive? The whole construct was quite dependent upon features such as price trends that in a gold standard would have to be reversed over the long run. It was not very well equipped to face the major shock that the war and its aftermath represented. The bad and good fortunes of the gold standard should, in fact, serve as a reminder that we all are accidents of history.

Table 1. The Extension of the Franchise:

Registered population as a \% of the eligible age group

\begin{tabular}{|c|c|c|c|c|c|c|}
\hline & & $18 \overline{1880}$ & 1890 & 1900 & 1910 & 1913 \\
\hline United Kingdom & & 35,8 & 62,4 & 61,5 & 62,2 & 62,4 \\
\hline France & & 86,4 & 86,6 & 90 & 91,5 & 90,5 \\
\hline Germany & & 91,3 & 92,3 & 94,2 & 94 & 86,8 \\
\hline Belgium & & 8,2 & 8,1 & 90,7 & 91,6 & 91,6 \\
\hline Netherlands & & 12,2 & 25,6 & 51,6 & 62,6 & 67 \\
\hline Switzerland & & 79,2 & 80,2 & 78,1 & 76,4 & 75,8 \\
\hline Denmark & & 78,3 & 84,2 & 85,4 & 87,9 & 87,8 \\
\hline Norway & & 23,7 & 32,2 & 89,7 & 95 & 95 \\
\hline Sweden & & 23,5 & 22,9 & 27,5 & 77,5 & 76,5 \\
\hline Italy & & 9 & 32 & 26,5 & 32,2 & 89,8 \\
\hline Spain & na & na & na & na & na & \\
\hline Portugal & na & na & na & na & na & \\
\hline Greece & na & na & na & na & na & \\
\hline Austria-Hungary & & 24,8 & 30,5 & 34,3 & 94,5 & 94,5 \\
\hline Russia & na & na & na & na & na & \\
\hline
\end{tabular}

Source: Flora et al. [1983], vol I, pp. 89 ff. 
Table 2. Central Bank Independence: Core Countries.

\begin{tabular}{|c|c|c|c|}
\hline & $\begin{array}{c}\text { Great-Britain } \\
\text { Bank of England }\end{array}$ & $\begin{array}{c}\text { France } \\
\text { Banque de France }\end{array}$ & $\begin{array}{c}\text { Germany } \\
\text { Reichsbank }\end{array}$ \\
\hline Status: & Private & Private & Private \\
\hline Head: & 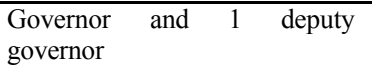 & 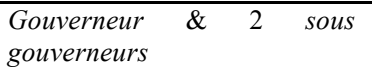 & President \\
\hline Appointed by: & Shareholders & Government & Imperial Government \\
\hline Council: & 24 Directors & Régents & $\begin{array}{l}4 \text { curators, the Chancellor, and } \\
\text { three delegates }\end{array}$ \\
\hline Appointed by: & Shareholders & Shareholders & $\begin{array}{l}1 \text { curator appointed by the } \\
\text { Chancellor, the others by the } \\
\text { Federal Council. } \\
3 \text { delegates appointed by the } \\
\text { shareholders participate to } \\
\text { board meetings (no vote) }\end{array}$ \\
\hline Cover system: & $\begin{array}{l}\text { Act of 1844: } 100 \% \text { specie } \\
\text { backing in the issue department, } \\
\text { plus fixed issues on "securities". } \\
\text { Suspension of the act of } 1844 \\
\text { required to issue beyong this } \\
\text { limit }\end{array}$ & $\begin{array}{l}\text { No formal rule (limits on } \\
\text { aggregate issues are regularly } \\
\text { revised upwards) }\end{array}$ & $\begin{array}{l}* \text { Fixed limit against which } \\
\text { reserve of } 1 / 3 \text { must be held. } \\
\text { Remaining } 2 / 3 \text { to be issued on } \\
\text { the basis of first class bills. } \\
* \text { issues beyond this figure must } \\
\text { have } 100 \% \text { cash backing } \\
\text { *Penalties beyond }\end{array}$ \\
\hline Parallel issues: & No & No & No \\
\hline Statutory advances: & $\begin{array}{l}\text { Yes } \\
\text { But very limited: "deficiency } \\
\text { advances" in the Banking } \\
\text { department under Parliament. } \\
\text { control }\end{array}$ & No obligation & $\begin{array}{l}\text { Possible (discount } \\
\text { government bills) }\end{array}$ \\
\hline Issues on govt sec: & Upper limit & No obligation & Possible \\
\hline StateÕs treasurer: & Yes & Yes, partly & Yes, (for free since 1909) \\
\hline Profits: & Shared & Rent to the state & Shared \\
\hline Monopoly: & Yes (quasi-monopoly) & Yes (since 1848) & $\begin{array}{l}\text { Yes (quasi-monopoly since } \\
1876 \text {, reinforced in 1899) }\end{array}$ \\
\hline Charter/revised: & $1833 / 1844$ & $1857 / 1897$ & $1875 / 1889 / 1899 / 1909$ \\
\hline Legal tender: & Acto of 1844 & Since 1870 & Not until 1909 \\
\hline
\end{tabular}

Source: Lévy [1911], Conant [1915] 
Table 3. Central Bank Independence: Small Countries

\begin{tabular}{|c|c|c|c|c|c|}
\hline & $\begin{array}{c}\text { Netherlands: de Nederlandsche } \\
\text { Bank }\end{array}$ & $\begin{array}{l}\text { Sweden: } \\
\text { Riksbank }\end{array}$ & $\begin{array}{c}\text { Norway } \\
\text { Norgesbank }\end{array}$ & $\begin{array}{c}\text { Denmark } \\
\text { Nationalbanken }\end{array}$ & $\begin{array}{c}\text { Belgium } \\
\text { Banque Nationale de } \\
\text { Belgique }\end{array}$ \\
\hline Status & Private & Government owned & $\begin{array}{l}\text { Private, but State is large } \\
\text { Shareholder }\end{array}$ & Private & Private \\
\hline $\begin{array}{l}\text { Head: } \\
\text { Appointed by: }\end{array}$ & $\begin{array}{l}\text { President (7 years) } \\
\text { Government }\end{array}$ & \multirow{2}{*}{$\begin{array}{l}\text { Commission that is not } \\
\text { responsible to the executive } \\
\text { govt, } \\
\text { and controlled by the Diet }\end{array}$} & $\begin{array}{l}\text { President and vice president } \\
\text { Government }\end{array}$ & $\begin{array}{l}5 \text { members in board of } \\
\text { directors } \\
1 \text { by govt, } 5 \text { by shareholders }\end{array}$ & $\begin{array}{l}\text { Governor } \\
\text { (5 years) } \\
\text { Government }\end{array}$ \\
\hline $\begin{array}{l}\text { Council: } \\
\text { Appointed by: }\end{array}$ & $\begin{array}{l}5 \text { regents } \\
\text { Shareholders }\end{array}$ & & $\begin{array}{l}5 \text { members } \\
\text { Shareholders }\end{array}$ & $\begin{array}{l}15 \text { members } \\
\text { Co-opted }\end{array}$ & $\begin{array}{l}6 \text { Directeurs } \\
\text { Shareholders }\end{array}$ \\
\hline Parrallel issue: & $\mathrm{NO}$ & $\mathrm{NO}$ & $\mathrm{NO}$ & $\mathrm{NO}$ & $\mathrm{NO}$ \\
\hline Statututory Advances: & $\begin{array}{l}\text { Yes, but very } \\
\text { limited }\end{array}$ & $\mathrm{NO}$ & $\mathrm{NO}$ & Yes, but ceiling & $\mathrm{NO}$ \\
\hline $\begin{array}{l}\text { Statutory issues on } \\
\text { govt sec.: }\end{array}$ & $\begin{array}{l}\text { Limited to a fraction of the } \\
\text { reserve and capital }\end{array}$ & $\begin{array}{l}\text { Yes, but limited } \\
\text { 3/8th of the } 40 \text { million } \\
\text { reserve }\end{array}$ & $\mathrm{NO}$ & Yes but very limited & $\begin{array}{l}\text { Yes, but very limited }(<50 \\
\text { millions })\end{array}$ \\
\hline State's Treasurer: & Yes & NO & Yes & Yes (state's cashier office) & Yes \\
\hline Monopoly & Yes & Yes, since 1904 & $\begin{array}{l}\text { Yes, if convertibility } \\
\text { maintained }\end{array}$ & Yes since 1818 & Yes since 1850 \\
\hline Chart/revised & $1863 / 1889 / 1903$ & $1887 / 1897 / 1904$ & $1816 / 1900$ & $1818 / 1907$ & $1850-1872-1900$ \\
\hline Legal tender & Yes & Yes & Yes & Yes & Yes, since 1873 \\
\hline
\end{tabular}

Source: Lévy [1911], Conant [1915], and for Denmark, private communication to the authors by Ingrid Henriksen and Hans Chr. Johansen. 


\section{Table 4. Central Bank Independence: Central and Eastern Europe}

\begin{tabular}{|c|c|c|c|c|}
\hline & $\begin{array}{c}\text { Russia } \\
\text { Bank of Russia } \\
\text { Before } 1894\end{array}$ & $\begin{array}{c}\text { Russia } \\
\text { Bank of Russia } \\
\text { After } 1894\end{array}$ & $\begin{array}{l}\text { Austria-Hungary } \\
\text { Oesterreischich- } \\
\text { Ungarischen Bank } \\
\text { Before } 1892\end{array}$ & $\begin{array}{l}\text { Austria-Hungary } \\
\text { Oesterreischich- } \\
\text { Ungarischen Bank } \\
\text { After } 1892\end{array}$ \\
\hline Status & State & State & Private & Private \\
\hline $\begin{array}{l}\text { Head: } \\
\text { Appointed by: }\end{array}$ & $\begin{array}{l}\text { Governor } \\
\text { Imperial government }\end{array}$ & $\begin{array}{l}\text { Governor } \\
\text { Imperial government }\end{array}$ & $\begin{array}{l}\text { Governor and } 2 \text { deputy } \\
\text { governors } \\
\text { Jointly appointed }\end{array}$ & $\begin{array}{l}\text { Governor and } 2 \text { deputy } \\
\text { governors } \\
\text { Jointly appointed }\end{array}$ \\
\hline $\begin{array}{l}\text { Council: } \\
\text { Appointed by: }\end{array}$ & Board of civil servants & Board of civil servants & $\begin{array}{l}\text { Council General (12 } \\
\text { members } \\
\text { Shareholders }\end{array}$ & $\begin{array}{l}\text { Council General (12 } \\
\text { members } \\
\text { Shareholders }\end{array}$ \\
\hline Cover System & None & $\begin{array}{l}1894 \text { : limit on issues } \\
1887 \text { without gold } \\
\text { backing } \\
1897: 50 \% \text { gold } \\
\text { backing for issues under } \\
600 \text { millions ruble, } \\
100 \% \text { cover beyond this } \\
\text { point }\end{array}$ & $\begin{array}{l}200 \text { milllion florind } \\
\text { unbacked issues } \\
\text { Reserves }>40 \% \\
\text { circulation }\end{array}$ & $\begin{array}{l}400 \text { million Crowns } \\
\text { unbacked issues } \\
\text { Reserves (1900) }\end{array}$ \\
\hline Parrallel issue: & Yes, unlimited & No & Yes & No \\
\hline Statututory Advances: & Yes, unlimited & No & $\begin{array}{l}\text { Yes, since } 1873 \\
\text { overdraft to both Austria } \\
\text { and Hungary }\end{array}$ & Very limited \\
\hline $\begin{array}{l}\text { Statutory issues on govt } \\
\text { sec.: }\end{array}$ & Yes, but limited & Yes, but limited & Yes & No \\
\hline State's Treasurer: & Yes & Yes & Yes & Yes \\
\hline Profits: & $100 \%$ go to the state & $100 \%$ go to the state & Shared & Shared \\
\hline Monopoly & Yes & Yes & Yes & Yes \\
\hline Chart/revised & $\begin{array}{l}\text { (statutes) } \\
1860 / 1894 / 1897 \\
\end{array}$ & $\begin{array}{l}\text { (statutes) } \\
1860 / 1894 / 1897 \\
\end{array}$ & $1878 / 87 / 97 / 1907$ & $1878 / 87 / 97 / 1907$ \\
\hline Legal tender & Yes & Yes & Yes & Yes \\
\hline
\end{tabular}


Table 5. Central Banks Independence: Southern Europe

\begin{tabular}{|c|c|c|c|c|}
\hline & $\begin{array}{c}\text { Portugal } \\
\text { Banco de Portugal }\end{array}$ & $\begin{array}{c}\text { Greece } \\
\text { National Bank of Greece }\end{array}$ & $\begin{array}{c}\text { Spain } \\
\text { Banca d'Espana }\end{array}$ & $\begin{array}{c}\text { Italy } \\
\text { Banca Nazionale/ } \\
\text { Banca d'Italia } \\
\end{array}$ \\
\hline Status & Private & Private & Private & Private \\
\hline Head: & Governor, vice-governor, & $\begin{array}{l}\text { Governor, } 2 \text { sub-governors } \\
\text { and one commisaire royal }\end{array}$ & Governor & Direttore Generale \\
\hline Appointed by: & $\begin{array}{l}\text { Government (Governor } 3 \\
\text { years), vice-governor from } \\
\text { list supplied by directors }\end{array}$ & $\begin{array}{l}\text { Elected by shareholders' } \\
\text { general assembly }\end{array}$ & Government & $\begin{array}{l}\text { Shareholders with } \\
\text { government } \\
\text { approval }\end{array}$ \\
\hline $\begin{array}{l}\text { Council: } \\
\text { Appointed by: }\end{array}$ & $\begin{array}{l}10 \text { directors } \\
\text { Shareholders }\end{array}$ & $\begin{array}{l}\text { Administrators } \\
\text { Shareholders }\end{array}$ & $\begin{array}{l}\text { Board } \\
\text { Shareholders }\end{array}$ & $\begin{array}{l}\text { Board } \\
\text { Shareholders }\end{array}$ \\
\hline Cover System & $\begin{array}{l}\text { Reserve ratios rules } \\
\text { Dismantled in the late } \\
1880 \text { s and early } 1890 \mathrm{~s}, \\
\text { never reimposed }\end{array}$ & $\begin{array}{l}1877: \text { limits on note issues } \\
1885: 1 / 3 \text { of issues backed } \\
\text { by gold }\end{array}$ & $\begin{array}{l}\text { 1874: } \text { specie }=1 / 4 \text { note issue } \\
\text { and note issue and max } \\
\text { issue }=750 \text { millions of ptas } \\
1891: \text { reserve }>1 / 3 \text { note } \\
\text { issue, gold }>1 / 2 \text { reserve, } \\
\text { and max issue }=1500 \\
\text { millions ptas } \\
1898: \text { max issue }=2500 \\
\text { mions ptas }\end{array}$ & $\begin{array}{l}\text { *1874-1884: under the } \\
\text { Consorzio limits on the } \\
\text { circulation of each bank of } \\
\text { issue. } \\
* 1891 \text { : each bank's max } \\
\text { issue is raised } \\
* 1893 \text { : gold and foreign } \\
\text { bills }>40 \% \text { note issue } \\
* \text { After } 1897 \text { Reserve must } \\
\text { be }>300 \text { then } 400 \text { millon } \\
\text { lira }\end{array}$ \\
\hline Parrallel issue: & No & No & No & No \\
\hline Advances: & $\begin{array}{l}\text { * limit of } 2000 \text { contos until } \\
1887 \\
* \text { Since } 1887 \text { : ceiling } \\
\text { renegotiated every year }\end{array}$ & $\begin{array}{l}\text { *In 1885; government } \\
\text { credit in exchange for larger } \\
\text { note issues } \\
\text { *Existing advances } \\
\text { converted into government } \\
\text { securities in } 1898\end{array}$ & $\begin{array}{l}\text { Yes: } \\
* \text { whole period ; up to } \\
125000000 \text { ptas (law of } \\
1874 \text { ) } \\
\text { *1890s credit by } \\
\text { discounting ultramar's } \\
\text { pagares } \\
\text { *1891-1893: extra credit of } \\
150 \text { mlns ptas } \\
* 1902 \text { : advances (except for } \\
\text { the } 150 \text { millions ptas credit) } \\
\text { must be reimbursed by } 1911\end{array}$ & $\begin{array}{l}\text { Yes } \\
* 1874-1884 \\
\text { Advances from Consorzio } \\
\text { against government } \\
\text { securities (up to } 1 \text { billion } \\
\text { lira) } \\
\text { *1884-1893: advances of } \\
\text { banks of issue against } \\
\text { deposit of government } \\
\text { securities } \\
\text { * After 1893: Limited. } \\
\text { Advances up to } 115 \text { million } \\
\text { lira.only }\end{array}$ \\
\hline Issues on govt sec.: & $\begin{array}{l}\text { * Limited until } 1887 . \\
\text { Yes, since } 1887\end{array}$ & $\begin{array}{l}* 1 / 3 \text { of note issues } \\
\text { according to law of } 1885 . \\
* \text { Short term debt } \\
\text { consolidated in } 1898 \text { must } \\
\text { be amortized }\end{array}$ & Yes: no limit & $\begin{array}{l}\text { *Before 1893: yes: banks } \\
\text { can take government bonds } \\
\text { in portfolio } \\
{ }^{*} \text { After } 1893 \text {, yes but not } \\
\text { beyond } 75 \text { millions. }\end{array}$ \\
\hline State's Treasurer: & Yes & Yes, some treasurer role & Yes & $\begin{array}{l}\text { Yes (increased } \\
\text { responsibilities across time) }\end{array}$ \\
\hline Profits: & Shared & Shared until 1892 & Nothing goes to the state & Only tax on circulation \\
\hline Monopoly & July 8,1891 & Quasi Monopoly in 1899 & 1874 & *Quasi-monopoly in 1893 \\
\hline Chart/revised & $1846 / 1887$ & $1841 / 1866 / 1903$ & $1856 / 1874 / 1899$ & 1893 \\
\hline Legal tender & $\begin{array}{l}\text { 1887-1891: } 5 \mathrm{~km} \text { around the } \\
\text { bank } \\
\text { 1891: Portugal }\end{array}$ & Yes (1885) & Yes (1874) & Yes (1893) \\
\hline
\end{tabular}

Table 6. Assessing the market mechanism. 
Table 6.a : "Rationing" (Pooling) : Equation (3).

\begin{tabular}{|c|c|c|c|c|c|c|c|c|c|c|}
\hline & $\alpha$ & $\beta_{1}$ & $\beta_{2}$ & On Gold & $\gamma$ & $\begin{array}{c}\text { implied } \\
\text { threshold }\end{array}$ & $\begin{array}{l}\mathrm{R}^{2} \\
\text { adj. }\end{array}$ & $\begin{array}{c}\text { Hausman } \\
\text { test }\end{array}$ & $\begin{array}{c}\text { Sargan } \\
\text { test }\end{array}$ & SBIC \\
\hline 1 & $\begin{array}{l}1.732 \\
(3.06)\end{array}$ & $\begin{array}{l}-0.958 \\
(-0.98)\end{array}$ & $\begin{array}{l}-1.627 \\
(-2.39)\end{array}$ & $\begin{array}{l}-0.528 \\
(-3.22) \\
\end{array}$ & $\begin{array}{c}0.356 \\
(10.18)\end{array}$ & $281 \%$ & 0.67 & $\begin{array}{c}\chi^{2}(3)=89.26 \\
(\mathrm{P}=0.00)\end{array}$ & $\begin{array}{c}\chi^{2}(1)=0.01 \\
(\mathrm{P}=0.92)\end{array}$ & 708.1 \\
\hline 2 & $\begin{array}{l}1.949 \\
(3.18)\end{array}$ & $\begin{array}{l}-0.041 \\
(-0.04)\end{array}$ & $\begin{array}{l}-2.052 \\
(-2.81)\end{array}$ & - & $\begin{array}{l}0.343 \\
(9.47)\end{array}$ & $292 \%$ & 0.66 & $\begin{array}{c}\chi^{2}(2)=61.54 \\
(\mathrm{P}=0.00)\end{array}$ & $\begin{array}{c}\chi^{2}(1)=0.03 \\
(\mathrm{P}=0.87)\end{array}$ & 710.2 \\
\hline 3 & $\begin{array}{l}2.037 \\
(3.15)\end{array}$ & $\begin{array}{l}-0.886 \\
(-1.01) \\
\end{array}$ & - & - & $\begin{array}{l}0.338 \\
(9.32)\end{array}$ & $296 \%$ & 0.65 & $\begin{array}{c}\chi^{2}(2)=9.19 \\
(\mathrm{P}=0.01)\end{array}$ & $\begin{array}{c}\chi^{2}(2)=0.25 \\
(\mathrm{P}=0.88)\end{array}$ & 712.6 \\
\hline 4 & $\begin{array}{l}1.949 \\
(3.17)\end{array}$ & - & $\begin{array}{l}-2.054 \\
(-2.92)\end{array}$ & - & $\begin{array}{l}0.343 \\
(9.52)\end{array}$ & $292 \%$ & 0.66 & $\begin{array}{c}\chi^{2}(2)=25.58 \\
(\mathrm{P}=0.00)\end{array}$ & $\begin{array}{c}\chi^{2}(2)=0.01 \\
(\mathrm{P}=0.99)\end{array}$ & 707.2 \\
\hline 5 & $\begin{array}{l}2.044 \\
(3.07)\end{array}$ & - & - & - & $\begin{array}{l}0.335 \\
(9.27)\end{array}$ & $299 \%$ & 0.65 & $\begin{array}{c}\chi^{2}(2)=18.90 \\
(\mathrm{P}=0.00)\end{array}$ & $\begin{array}{c}\chi^{2}(3)=0.45 \\
(\mathrm{P}=0.93)\end{array}$ & 709.7 \\
\hline
\end{tabular}

Table 6.b : "Linear" (Pooling) : Equation (4)

\begin{tabular}{|c|c|c|c|c|c|c|c|c|}
\hline & $\alpha$ & $\beta_{1}$ & $\beta_{2}$ & On Gold & $\mathrm{R}^{2}$ adj. & $\begin{array}{c}\text { Hausman } \\
\text { test }\end{array}$ & $\begin{array}{c}\text { Sargan } \\
\text { test }\end{array}$ & SBIC \\
\hline 1 & $\begin{array}{l}5.645 \\
(4.69) \\
\end{array}$ & $\begin{array}{l}3.838 \\
(2.94)\end{array}$ & $\begin{array}{l}-1.708 \\
(-2.36)\end{array}$ & $\begin{array}{l}-0.398 \\
(-1.36) \\
\end{array}$ & 0.62 & $\begin{array}{c}\chi^{2}(2)=12.40 \\
(\mathrm{P}=0.00)\end{array}$ & $\begin{array}{c}\chi^{2}(1)=0.02 \\
(\mathrm{P}=0.90)\end{array}$ & 735.6 \\
\hline 2 & $\begin{array}{l}5.877 \\
(5.27)\end{array}$ & $\begin{array}{l}4.287 \\
(3.36)\end{array}$ & $\begin{array}{l}-1.929 \\
(-2.42)\end{array}$ & - & 0.62 & $\begin{array}{c}\chi^{2}(2)=10.42 \\
(\mathrm{P}=0.01)\end{array}$ & $\begin{array}{c}\chi^{2}(1)=0.01 \\
(\mathrm{P}=0.91)\end{array}$ & 733.8 \\
\hline 3 & $\begin{array}{l}6.315 \\
(6.24) \\
\end{array}$ & $\begin{array}{l}3.326 \\
(2.69)\end{array}$ & - & - & 0.61 & $\begin{array}{c}\chi^{2}(1)=6.83 \\
(\mathrm{P}=0.01)\end{array}$ & $\begin{array}{c}\chi^{2}(2)=0.13 \\
(\mathrm{P}=0.93)\end{array}$ & 733.7 \\
\hline 4 & $\begin{array}{l}5.768 \\
(5.15)\end{array}$ & - & $\begin{array}{l}-1.569 \\
(-2.00)\end{array}$ & - & 0.61 & $\begin{array}{c}\chi^{2}(2)=9.12 \\
(\mathrm{P}=0.01)\end{array}$ & $\begin{array}{c}\chi^{2}(2)=0.13 \\
(\mathrm{P}=0.94)\end{array}$ & 733.2 \\
\hline 5 & $\begin{array}{l}6.160 \\
(6.16)\end{array}$ & - & - & - & 0.61 & $\begin{array}{c}\chi^{2}(1)=2.19 \\
(\mathrm{P}=0.14)\end{array}$ & $\begin{array}{c}\chi^{2}(3)=0.06 \\
(\mathrm{P}=0.99)\end{array}$ & 732.3 \\
\hline
\end{tabular}

Table 6.c : "Punishing" (Pooling) : Equation (2) 


\begin{tabular}{|c|c|c|c|c|c|c|c|c|}
\hline & $\alpha$ & $\beta_{1}$ & $\beta_{2}$ & On Gold & $\mathrm{R}^{2}$ adj. & $\begin{array}{c}\text { Hausman } \\
\text { test }\end{array}$ & $\begin{array}{c}\text { Sargan } \\
\text { test }\end{array}$ & $\overline{\mathrm{SBIC}}$ \\
\hline 1 & $\begin{array}{l}1.449 \\
(6.28)\end{array}$ & $\begin{array}{c}-16.426 \\
(-3.43)\end{array}$ & $\begin{array}{l}-3.213 \\
(-5.08)\end{array}$ & $\begin{array}{l}-0.345 \\
(-3.39)\end{array}$ & 0.81 & $\begin{array}{c}\chi^{2}(1)=20.19 \\
(\mathrm{P}=0.00)\end{array}$ & $\begin{array}{c}\chi^{2}(1)=0.03 \\
(\mathrm{P}=0.87)\end{array}$ & 595.5 \\
\hline 2 & $\begin{array}{l}1.490 \\
(6.32)\end{array}$ & $\begin{array}{c}-15.451 \\
(-3.03)\end{array}$ & $\begin{array}{l}-3.652 \\
(-6.43)\end{array}$ & - & 0.80 & $\begin{array}{c}\chi^{2}(2)=15.08 \\
(\mathrm{P}=0.00)\end{array}$ & $\begin{array}{c}\chi^{2}(1)=0.01 \\
(\mathrm{P}=0.91)\end{array}$ & 601.0 \\
\hline 3 & $\begin{array}{l}2.025 \\
(7.75) \\
\end{array}$ & $\begin{array}{l}-10.06 \\
(-2.66) \\
\end{array}$ & - & - & 0.72 & $\begin{array}{c}\chi^{2}(1)=12.05 \\
(\mathrm{P}=0.00)\end{array}$ & $\begin{array}{c}\chi^{2}(2)=0.48 \\
(\mathrm{P}=0.79)\end{array}$ & 665.8 \\
\hline 4 & $\begin{array}{l}1.471 \\
(5.91) \\
\end{array}$ & - & $\begin{array}{l}-3.476 \\
(-5.74) \\
\end{array}$ & - & 0.79 & $\begin{array}{c}\chi^{2}(3)=31.90 \\
(\mathrm{P}=0.00)\end{array}$ & $\begin{array}{c}\chi^{2}(2)=0.35 \\
(\mathrm{P}=0.84)\end{array}$ & 610.6 \\
\hline 5 & $\begin{array}{l}2.041 \\
(7.36) \\
\end{array}$ & $\begin{array}{l}-1.457 \\
(-5.89) \\
\end{array}$ & - & - & 0.72 & $\begin{array}{c}\chi^{2}(3)=7.93 \\
(\mathrm{P}=0.05)\end{array}$ & $\begin{array}{c}\chi^{2}(3)=1.14 \\
(\mathrm{P}=0.77)\end{array}$ & 666.7 \\
\hline
\end{tabular}

Notes: Number of observations : 398. Numbers in parentheses are heteroscedasticity consistent Student t's (corresponding standard errors are computed from heteroscedastic-consistent matrix (White)).

Note: Frequently in practice, some elements of the difference in the covariance matrices of the two sets of estimates are negative on the diagonal. If this is the case, the Hausman test should be computed only for those parameters corresponding to positive diagonal elements, with a corresponding correction to the degrees of freedom, which is what our program does. (One has to use a generalized inverse in the many cases in which the covariance matrix of the vector of contrasts does not have full rank. See Hausman and Taylor (1982)).

Note: The above tables report the results for instrumented regressions. The instruments used were a constant term, a time trend, the rate of growth of the country's population, the first lag of the debt to GDP ratio for each country, and the burden of interest service for each country (IR/Rev where Rev is government revenue and IR is interest payment on the public debt). Regressions involving different sets of instruments are reported in the annex.

Source: Authors' computations (see text for methodology). 
Box 1: The linear, punishing and rationing models.

Consider the following arbitrage relation, which states that for a risk neutral investor, the expected return for a risky bond must equal the expected return for a risk free bond, say a British Consol ( $s_{i t}$ represents the risk premium charged on currency $i$ at date $t$ ):

$$
\left(1+\mathrm{R}_{\mathrm{UKt}}+\mathrm{s}_{\mathrm{it}}\right) \bullet \mathrm{P}\left(\mathrm{H}_{\mathrm{t}}\right)+0 \bullet\left(1-\mathrm{P}\left(\mathrm{H}_{\mathrm{t}}\right)\right)=1+\mathrm{R}_{\mathrm{UKt}}
$$

Where $R_{i t}=R_{u k t}+s_{i t}$ stands for interest rate charged to country $i$ at date $t$ ( $s_{i t}$ is the default premium, $\mathrm{P}\left(\mathrm{H}_{\mathrm{it}}\right)$ is the probability of default, $\mathrm{P}^{\prime}\left(\mathrm{H}_{\mathrm{it}}\right)<0$, and $\mathrm{H}_{\mathrm{it}}$ is a variable summarizing the determinants of default (we abstract from taxation as a large proportion of the bonds studied here were exempt from tax duties). Getting rid of the country and time indices, assuming that $\mathrm{P}(\mathrm{H})$ is a logistic function $(\mathrm{P}(\mathrm{H})=1 /(1+\exp (\mathrm{H})))$, and writing $\mathrm{H}=\alpha \mathrm{B} / \mathrm{GDP}+\mathrm{X}{ }^{\prime} \beta$ (where $\mathrm{B} / \mathrm{GDP}$ is the debt/GDP ratio and $\mathrm{X}$ is a vector of exogenous variables influencing the probability of default), we get the following model:

$$
s=\exp \left(\alpha \frac{B}{G D P}+\beta_{0}+\beta_{1} \frac{E X}{G D P}+\beta_{2} \frac{G D P}{P O P}\right)+\varepsilon
$$

Which is non-linear: we call this expression the «credit punishing » equation, where EX/GDP is the exports to GDP ratio, and GDP/POP is real GDP per head converted at PPP prices. In this formulation, the default premium grows exponentially with the debt level, but there is no absolute limit to borrowing.

Another formulation is to model the default premium as an increasing function of B/GDP, but with an upper limit on debt accumulation. This can be done if one assumes that the whole debt is reimbursed and reissued at every period (see Bayoumi et al. [1995]). This allows to identify the marginal cost of borrowing $\left(\mathrm{R}_{\mathrm{i}}\right)$ with the average cost of servicing the total debt (the interest burden on the outstanding debt). In this case, the formula assumes that the derivative of the cost of borrowing with respect to the debt/GDP ratio converges towards infinity when the debt GDP ratio approaches a certain threshold (equal to $1 / \gamma$ ). Formally:

$$
s=\left(\alpha \frac{B}{G D P}+\beta_{0}+\beta_{1} \frac{E X}{G D P}+\beta_{2} \frac{G D P}{P O P}\right) \bullet \frac{1}{1-\gamma \frac{B}{G D P}}+\varepsilon
$$

We call this equation the " credit-rationing hypothesis ", as it shows that the default premium rises to infinity when the debt GDP ratio approaches $1 / \gamma$ : borrowers are prevented from increasing their debt beyond $1 / \gamma$. These two formulations are to be contrasted with an alternative linear relation between the default premium and the debt to GDP ratio. Formally:

$$
s=\alpha \frac{B}{G D P}+\beta_{0}+\beta_{1} \frac{E X}{G D P}+\beta_{2} \frac{G D P}{P O P}+\varepsilon
$$

Which is referred to in the text as the linear form of the market discipline hypothesis. 


\section{APPENDIX A. DATA}

We rely on a combination of second-hand sources as well as primary material that we collected, covering the period 1880-1913.

\section{A1. Public debts and interest service}

Researchers working on nineteenth-century public finance typically rely on published sources such as Mitchell (1993) and Liesner (1989). Before the creation of the League of Nations in the interwar period, no centralized statistical office existed, so that researchers have to centralize data themselves, putting together national figures: this is the approach followed by Mitchell. The problem is that Mitchell's fiscal figures (which are very imperfect in many respects) do not include public debts. On the other hand, reliable second-hand national data on public debts exist for only a few countries, including Mitchell (1990) for Britain, Gerloff (1912) for Germany, Zamagni (1997) for Italy, and Pirard (1978) for Belgium. To complete our database we used the returns of Macmillan's Statesman's Year Book, as well as the publications of the Société Internationale de Statistique, which brought together some of the most famous statisticians of the time. Neymarck (1913) contains some interesting complementary information. Finally, we used the archives of the Crédit Lyonnais, which before the First World War had a research department that was very active and appropriately staffed. These sources helped fill the holes in existing sources for both debt figures and interest service. Debt returns are all inclusive: that is, they take into account the short-term floating debt as well as the long-term funded debt, the domestic paper debt, as well as the external gold debt, evaluated in nominal terms and converted into the national unit. 


\section{A2. National product and prices}

Recently, substantial efforts have been devoted to extending our knowledge of European accounts well beyond pioneering works on core countries. We were able to obtain reliable data for virtually every country in the sample. The references are as follows: Austria-Hungary: Komlos (1987) and Schulze (1997); France: Lévy-Leboyer and Bourguignon (1985); Germany: Hoffmann et al. (1965); Greece: Kostelenos (1995) ; Spain: Prados de la Escosura (1995); Portugal: Nunes et al. (1989) and Lains and Reis (1991); England: Mitchell (1990); Russia: Gregory (1994); Netherlands: Smits et al. (1997); Sweden: Johansson (1967); Denmark and Norway: Mitchell (1993). For Belgium and Switzerland, a series was reconstructed on the basis of end-of period estimates as well as of indications for real GDP growth given in Maddison (1991). Swiss prices are found in Ritzmann (1996).

\section{A3. Exchange rates}

The exchange rates used were constructed on the basis of Schneider et al. (1991), except for Greece, for which we used a Lyonnais series. Data are annual averages. 


\section{A4. Exports}

We relied exclusively on Mitchell (1993), except for the Netherlands, for which the figures are flawed. Dutch exports are from Smits et al. (1997).

\section{A5. Population}

Data in Mitchell (1993) completed by Gregory (1994) for Russia and by the Crédit Lyonnais returns for the Austro-Hungarian Empire.

\section{A6. Long-term interest rates}

The classic source for long-term interest rates on government (gold) bonds is Homer and Sylla (1991). However, the returns that these authors report cover only part of our sample. For countries that are not documented in this source, and which typically include the continental countries for which Paris was an essential financial centre (Portugal, Spain, Greece, Russia and the Scandinavian countries for the latter part of the period under study), we used the Cours Authentiques. Quarterly figures were collected, on the basis of which annual interest rates were constructed. In order to select representative bonds, we used the information provided in the Annuaire Officiel des Agents de Changes, which describes the various bonds listed. Data availability as well as conversions, forced or not, required us in some cases to change our reference bond, or to make some simple transformations when the coupon was changed (in all cases, we checked that when they overlap, series for various bonds implied extremely close returns, as arbitrage theory predicts). 
The series we use are gold consols: Austria (coupon: 4\%); Denmark (1893 with a 3\% coupon); Sweden (4\% of $1878,3 \%$ bond of $1888,3.5 \%$ of 1895$)$; Norway $(3.5 \%$ of 1886 , $3 \%$ of 1888 ); Portugal (3\% coupon, reduced in 1892 and 1902$)$; Greece (5\% of $1881,5 \%$ of 1884 reduced in 1893); Russia (5\% of 1877 until 1889, then $4 \%$ of 1880 until 1914); Switzerland (3\% of $1890,3.5 \%$ of 1887 and $3 \%$ of 1897). For Spain, until 1882 we used the 3\% 'extérieure', replaced in 1882 by a $4 \%$ consol (Spanish residents faced a forced conversion in 1898 into paper consols, but foreigners continued to get their coupon paid into gold). For Italy we use the rendita $5 \%$, converted to $3.5 \%$ in 1906 . The sample covers $1880-1913$, except for Greece (1884-97 and 1905-13), Norway (1887-1913), Switzerland (1899-1912) and Russia (1885-1912). 


\section{APPENDIX B. ADDITIONAL ROBUSTNESS TESTS}

\section{B1. Specification tests}

Various techniques were used to test the three specifications presented in panels (a), (b) and

performed a test of the 'linear' versus 'punishing' specifications, using a Box-Cox transformation (Box and Cox, 1964) of the left-hand-side variables, which allows us to test a model versus a semi-log model. Again, the linear model was rejected. ${ }^{14}$

hand, the 'punishing' and 'rationing' specifications cannot be directly tested against each other, since they are not nested. Instead we performed pseudo-nested tests based on the artificial competing functions in a more general form in order to discriminate between them. MacKinnon et al pairs of J-tests and P-tests we computed (for each set of explanatory variables) were never able to distinguish between the 'rationing' and the 'punishing' specifications, and could not reject

In another attempt to discriminate between the two non-linear models, we computed a model selection test, known as the Schwarz Bayesian Information Criteria (SBIC), which has alternatives being tested (see Geweke and Meese, 1981). We observe that in all cases the

\footnotetext{
14 Pseudo-nested P-Tests also pointed to the same conclusion.
} 
criteria favour the punishing specification. Again, we read this result as supportive of the idea of a non-linear steep supply curve facing state borrowers, irrespective of the specific functional form.

\section{B2. Sensitivity}

In Table B1 we provide results for regressions that exclude problem countries in an attempt to check for the stability of the coefficient. While removing Greece (a high-debt country) has the mechanic effect of lowering estimated rationing levels, these remain very high (180\%). In Table B2, we report the results of regressions that allow for random effects (linear and punishing equations). As can be seen, parameter estimates are robust to the introduction of random effects.

\section{B3. Instruments}

To decide wether it is necessary to use instrumental variables, we first perform a Hausman-Wu specification test (Hausman, 1978) reported in Table 6 for each regression. The test generally rejects the equality of the two sets of estimated coefficients (instrumental variables versus nonlinear least squares), indicating the need to use instrument variables techniques (Davidson and MacKinnon (1993) indicate how this test is applicable to non-linear models). Second, we test for the adequacy of our instruments by regressing the appropriate independant variables on our instruments set. In all three cases, an F-test rejects the hypothesis that the instruments are jointly insignificant (results not reported). Third, we test the validity of our choice of instruments using a Sargan test (Sargan, 1958; Mátyás and Sevestre (1996) consider the use of the Sargan test in the context of panel data econometrics, and Davidson and MacKinnon 
(1993) show the analogue of the test for non-linear models). The success of the test (see Table 6) implies that all of the explanatory power of the instruments is being captured in the independent variables. Finally, we have tried alternative subsets of instruments with the rationing equation, again in order to assess parameter stability. Table B3 shows that the parameter estimates and the implied rationing thresholds are stable. 
Table B1. Sensitivity to possible outliers : the cases of Greece and Portugal.

\begin{tabular}{lcccc}
\hline \hline & $\alpha$ & $\gamma$ & $\begin{array}{c}\text { implied } \\
\text { threshold }\end{array}$ & $\begin{array}{c}\mathrm{R}^{2} \\
\text { adj. }\end{array}$ \\
\hline Portugal & 1.647 & $\begin{array}{c}0.357 \\
(13.24)\end{array}$ & & 0.74 \\
\hline Regression without & 2.778 & & $180 \%$ & \\
& $(7.82)$ & $(16.83)$ & & \\
\hline \hline
\end{tabular}

Note : We only report

(the linear and punishing specifications having yielded almost identical results as the general regressions). Results when both countries were excluded are similar to the ones without

Table B2. Random effects

\begin{tabular}{lcccccc}
\hline \hline & $\alpha$ & 0 & $\beta$ & $\beta_{2}$ & & $\mathrm{R}^{2}$ \\
& & & & & & \\
\hline Linear & 4.744 & -0.721 & & -0.742 & -0.588 & \\
& & $(-0.90)$ & $(0.62)$ & & $(-2.32)$ & \\
\hline Punishing & 0.821 & 1.105 & & -1.998 & -0.208 & $(-2.63)$ \\
& & $(4.28)$ & $(-2.47)$ & & $(-2.63)$ & \\
\hline \hline
\end{tabular}

Note :

specifications. Random effects in the rationing model involve specific techniques that would require

Hausman Tests of FE versus RE showed FE for the above regressions, but RE for other regressions with less explanatory variables. In all cases, F-tests choose FE versus

Table B3. Different sets of instruments

\begin{tabular}{|c|c|c|c|c|c|c|c|}
\hline instruments used : & & $\beta_{1}$ & 2 & $\overline{\mathrm{O} \text { On }}$ & $\gamma$ & $\begin{array}{c}\text { implied } \\
\text { d }\end{array}$ & $\mathrm{R}$ adj \\
\hline C,TIME,POP,IR/Rev & $(0.48)$ & -0.295 & $\begin{array}{l}-1.049 \\
(-1.86) \\
\end{array}$ & $(-4.13)$ & 0.395 & $253 \%$ & 0.62 \\
\hline explanatory variables & 1.681 & $\begin{array}{l}-0.485 \\
(-0.45)\end{array}$ & $(-2.71)$ & -0.535 & $\begin{array}{l}0.357 \\
(8.75)\end{array}$ & & 0.69 \\
\hline C,TIME,POP,B/GDP(-1) & $(2.97)$ & -1.030 & $\begin{array}{l}-1.311 \\
(-2.54)\end{array}$ & $(-3.30)$ & 0.355 & $282 \%$ & 0.67 \\
\hline & $\begin{array}{l}1.751 \\
(3.39)\end{array}$ & $(-0.75)$ & -1.799 & $\begin{array}{l}-0.534 \\
(-3.22)\end{array}$ & $(8.51)$ & $294 \%$ & \\
\hline
\end{tabular}

Source: Authors' computations (see text for methodology).

: The full set of possible instrument is : a constant term, a time trend, the rate of growth of countries' populations(POP), the burden of interest service for each country (IP/Rev), the 
Alesina, A. (1994). 'Comment', in NBER Macroeconomics Annual

MA.

Bairoch, P. (1974), 'Geographical structure and trade balance of European foreign trade from Journal of European Economic History.

Economics and World History: Myths and Paradoxes, Harvester Wheatsheaf,

Barsky, R. and J. Bradford De Long (1991). 'Forecasting pre WWI inflation: the Fisher effect and the gold standard',

Baxter, R.D. (1871). ～(2nd edn), Robert John Bush, London.

Bayoumi, T. (1990). 'Saving-investment correlations: immobile capital, government policy, or IMF Staff Papers.

borrowers? Evidence from the US states', Journal of Money, Credit and Banking

Bishop, G., D. Damrau and M. Miller (1989). 1992 and Beyond: Market Discipline Can Work , Salomon Brothers, London.

Bloomfield, A. (1959). 'Monetary policy under the international gold standard, 1880-1914', (1963). 'Short-term capital movements under the pre-1914 gold standard' Essays in International Finance.

'The gold standard as a good housekeeper seal of approval',

Bouvier, J. (1988). 'The Banque de France and the state from 1850 to the present day', in G. Central Banks' Independence in Historical Perspective, Walter de 
Box, G.E.P. and D.R. Cox (1964). 'An analysis of transformations', Journal of the Royal Statistical Society.

Capie, F., C. Goodhart, S. Fisher and N. Schnadt (eds.) (1994). The Future of Central Banking, Cambridge University Press, Cambridge.

(1997). 'Central bank statutes: the historical dimension', Die Bedeutung der Unabhängigkeit der Notenbank für die Glaubwürdigkeit der Europäischen Geldpolitik/Proceedings of the 25th Conference of the Österreichische Nazionalbank.

Cerrito, E. (1995). 'Su alcuni aspetti della crisi del 1893 in Italia', in P. Macry and A. Massafra (eds.), Fra Storia e Storiografia: Scritti in onore di Pasquale Villani, Il Mulino, Bologna.

Conant, C. (1915). A History of the Banks of Issue (2nd edn), Putnam's, New York and London..

Cukierman, A. (1992). Central Bank Strategy, Credibility, and Independence, MIT Press, Cambridge, MA.

Davidson, R. and J. G. MacKinnon (1981). 'Several tests for model specification in the presence of alternative hypotheses', Econometrica.

_ (1993). Estimation and Inference in Econometrics, Oxford University Press, Oxford.

Eichengreen, B. (1992). Golden Fetters: The Gold Standard and the Great Depression, 19191939, Oxford University Press, Oxford.

Eichengreen, B. (1996). Globalizing Capital: A Short History of the International Monetary System, Princeton University Press, Princeton, NJ.

Eichengreen, B. and M. Flandreau. (1996). 'The geography of the gold standard', in B. Eichengreen, J. Reis and J. Braga De Macedo (eds.), Currency Convertibility: The Gold Standard and Beyond, Routledge, London.

Eichengreen, B. and M. Flandreau (1997). The Gold Standard in Theory and History (2nd edn), Routledge, London. 
Flandreau, M. (1995a). L’Or du monde: La France et la stabilité du système monétaire , Etudes d'Economie Politique, L'Harmattan, Paris.

(1995b).'Was the Latin Union a franc zone?', in J. Reis (ed.),

Systems in Historical Perspective, Macmillan, London.

standard', Journal of Economic History

Flood, R.P. and P.M. Garber (1984). 'Gold monetization and gold discipline', Journal of

Flora, P. et al. (1983).

Handbook in Two Volumes, Campus Verlag, Frankfurt.

The Gold Standard 1880-1914: Britain and Argentina, Clarendon,

— (1989). 'International financial policies and the gold standard, 1870-1914', in P. Mathias and S. Pollard (eds.), , vol. VIII, Cambridge University Press, Cambridge.

J. Driffil and M. Beder (eds.), A Currency for Europe London.

Gallarotti, G. (1995). , Oxford University Press, Oxford.

Die Finanz und Zollpolitik des Deutschen Reiches, Verlag von Gustav

Geweke, J.F. and R. Meese (1981). 'Estimating regression models of finite but unknown order',

Goodhart, C. (1988). , MIT Press, Cambridge, MA. 
Gregory, P. (1994). Before Command, Princeton University Press, Princeton, NJ.

Haupt, O. (1894). Arbitrages et Parités, Librairie Truchy, Ch. Leroy, Successeur, Paris.

Hausman, J.A. (1978). 'Specification tests in econometrics', Econometrica.

— and W.E. Taylor (1982). 'A generalized specification test', Economics Letters.

Hoffmann, W. et al. (1965). Das Wachstum der deutschen Wirtschaft seit der Mitte des 19. Jahrhunderts, Springer, Heidelberg.

Holtfrerich, C.-L. (1988). 'The relations between monetary authorities and government institutions: the case of Germany from the nineteenth century to the present', in G. Toniolo (ed.), Central Banks' Independence in Historical Perspective, Walter de Gruyter, Berlin.

Homer, S. and R. Sylla (1991). A History of Interest Rates, Rutgers University Press, Rutgers.

James, H. (1997). 'From Bismarck to Kohl: monetary and fiscal unification in nineteenth century Germany as a model for the European Union?', Princeton Essays in International Finance.

Johansson, O. (1967). 'The gross domestic product of Sweden and its composition, 18611955', Stockholm Economic Studies.

Kindleberger, C.P. (1988). Keynesianism vs Monetarism and other Essays in Financial History, Allen and Unwin, London, Boston and Sydney.

Komlos, J. (1987). 'Financial innovation and the demand for money in Austria-Hungary, 18671913', Journal of European Economic History.

Kostelenos, G.C. (1995). Money and Output in Modern Greece, 1858-1938, Centre of Planning and Economic Research, Athens.

Lains, P. and J. Reis (1991). 'Portuguese economic growth, 1833-1985: some doubts', Journal of European Economic History.

Lévy, R.G. (1911). Banques d'émission et Trésors publics, Economiste Européen, Hachette, Paris. 
Lévy-Leboyer, M. and F. Bourguignon (1985). L'Economie française au XIXème siècle, Economica, Paris.

Liesner, T. (1989). One Hundred Years of Economic Statistics, Economist Publications, London.

MacKinnon, J.G., H. White and R. Davidson (1983). 'Tests for model specification in the presence of alternative hypotheses: some further results', Journal of Econometrics.

Maddison, A. (1991). Dynamic Forces in Capitalist Development: A Long-Run Comparative View, Oxford University Press, Oxford.

Mátyás, L. and P. Sevestre (eds.) (1996). The Econometrics of Panel Data: A Handbook of the Theory with Applications (2nd revised edn), Kluwer, Dordrecht.

McCloskey, D. and R. Zecher (1984). 'The success of purchasing power parity: historical evidence and its implications for macroeconomics', in M. Bordo and A. Schwartz, $A$ Retrospective on the Classical Gold Standard, University of Chicago Press, Chicago, IL.

Mélitz, J. (1997). 'Market discrimination between the debts of different sovereigns under EMU', unpublished manuscript.

Mitchell, B.R. (1990). British Historical Statistics, Cambridge University Press, Cambridge.

— (1993). International Historical Statistics: Europe 1750-1988, Stockton Press, New York.

Morgenstern, O. (1959). International Financial Transactions and Business Cycles, Princeton University Press, Princeton, NJ.

Muhleman, M. (1897). Monetary Systems of the World, Charles Nicoll, New York.

Neisser, H. (1929, 1930). 'Der internationale Geldmarkt vor und nach dem Kriege', Weltwirtschaftliches Archiv. 
Neymarck, A. (1913). 'La statistique internationale des valeurs mobilières' (IXème Rapport de M. Alfred Neymarck), Bulletin de l'institut international de statistique, Van Stockum, La Haye.

Nunes, A., E. Mata and N. Valerio (1989). 'Portuguese economic growth', Journal of European Economic History.

Pirard, J. (1978). 'La dette publique belge de 1830 à 1913', in 9e colloque international, La Dette publique aux XVIIIe et XIXe siècles son développement sur le plan local, régional et national, Spa, 12-16 September.

Plessis, A. (1985). La Politique de la Banque de France sous le Second Empire, Droz, Geneva.

Polanyi, K. (1944). The Great Transformation, Rinchard, New York.

Posen, A. (1994). 'Declarations are not enough: financial sector sources of central bank independence', NBER Macroeconomics Annual, MIT Press, Cambridge, MA.

Prados de la Escosura, L. (1995). 'Spain's gross domestic product: 1850-1993: quantitative conjectures' and 'Appendix', Working Papers, 95-05 and 95-06, Universidad Carlos III de Madrid.

Raffalovich, A. (1900). 'Les méthodes employées par les Etats au XIXème Siècle pour revenir à la bonne monnaie', Congrès International des Valeurs Mobilières, Paris.

Ritzmann, H. (1996). Historical Statistics for Switzerland, Chronos Verlag, Zurich.

Russell, H.B (1898). International Monetary Conferences, Harper, London.

Sargan, J.D. (1958). 'The estimation of economic relationships using instrumental variables', Econometrica.

Schneider, J., O. Schwarzer and F. Zellfelder (1991). Währungen der Welt I, Verlag, Stuttgart. Schulze, M.-S (1997). 'Re-estimating Austrian GDP, 1870-1913: methods and sources', Working Papers in Economic History, no. 36/97, LSE, London. 
Smits, J.P., E. Horlings and J.L. Van Zanden (1997). 'The measurement of gross national product and its components: the Netherlands, 1800-1913', research memorandum, N.W. Posthumus Insituut, Netherlands Graduate School for Economic and Social History.

Statesman's Year Book, annual, since 1866.

Stiglitz, J. and A. Weiss (1981). 'Credit rationing in markets with imperfect information', American Economic Review.

Taylor, A.M. (1996). 'International capital mobility in history: the saving-invesetment relationship', NBER Working Paper no. 5743.

Théry, E. (1894). La Crise des changes, Etudes Economiques et Financières, Economiste Européen, Paris.

Triffin, R. (1964). 'The myth and realities of the so-called gold standard', in The Evolution of the International Monetary System: Historical Reappraisal and Future Perspectives, Princeton University Press, Princeton, NJ.

Verley, P. (1997). L'Echelle du monde, Albin Michel, Paris.

Williamson, J. (1996). 'Globalization, convergence and history', Journal of Economic History.

Yeager, L.B. (1969). 'Fluctuating exchange rates in the 19th century: the experiences of Russia and Austria', in R. Mundell and A. Swoboda (eds.), Monetary Problems of the International Economy, University of Chicago Press, Chicago, IL.

Zamagni, V. (1997). 'Ricostruzione della serie del debito pubblico italiano, 1861-1946,' mimeo.

Zevin, R.B. (1992). 'Are world financial markets more open? If so, why and with what effects?', in T. Banuri and J. Schor (eds.), Financial Openness and National Autonomy, Oxford University Press, Oxford. 
Figure 1. Countries on Gold, 1880-1913

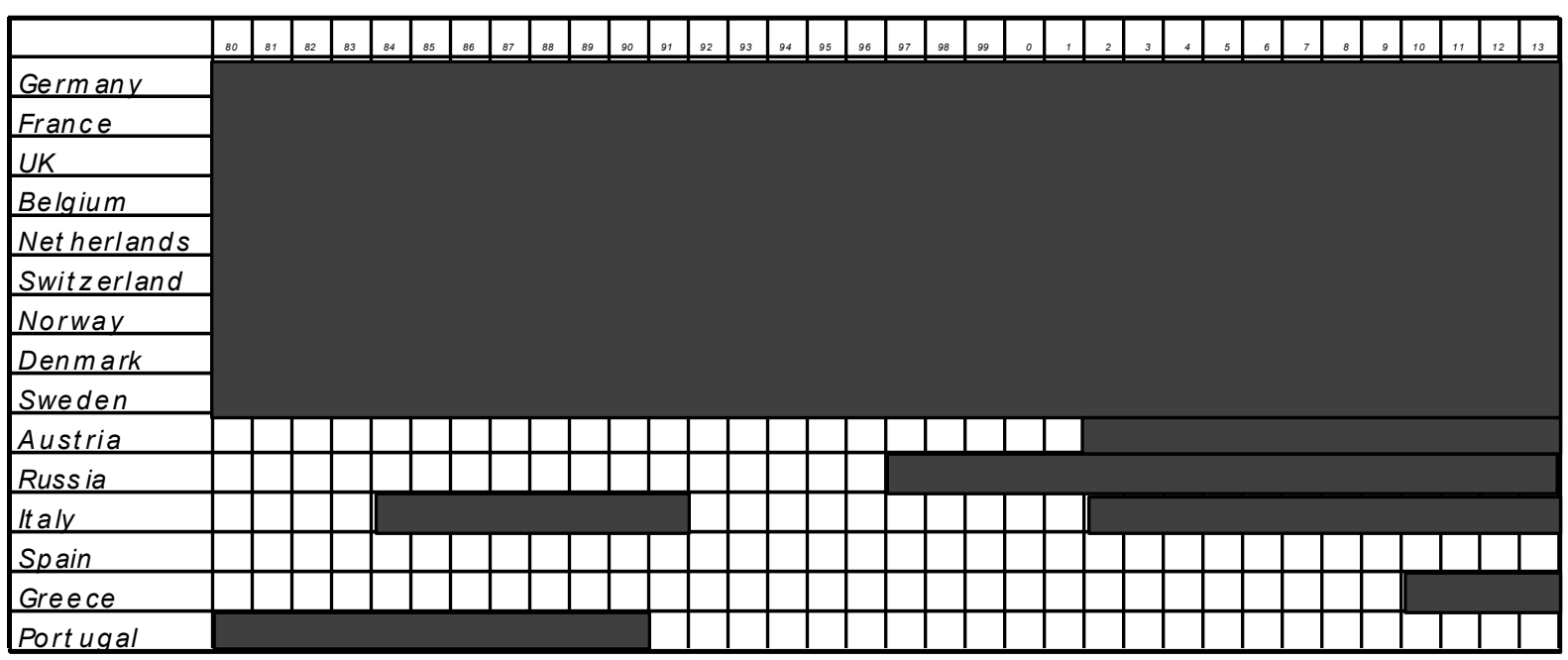

